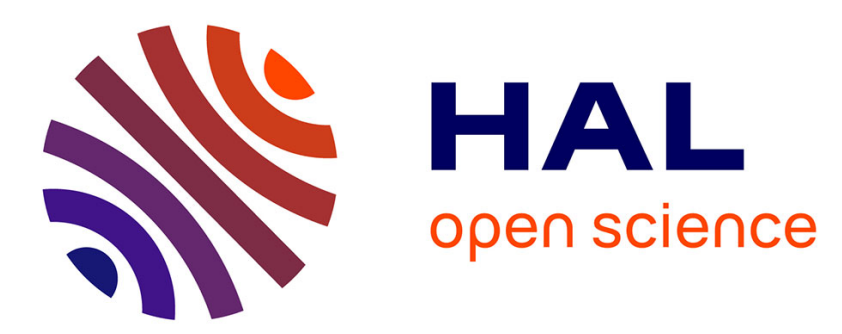

\title{
Interaction between normal fault slip and erosion on relief evolution: Insights from experimental modelling
}

Vincent Strak, Stéphane Dominguez, Carole Petit, Bertrand Meyer, Nicolas Loget

\section{- To cite this version:}

Vincent Strak, Stéphane Dominguez, Carole Petit, Bertrand Meyer, Nicolas Loget. Interaction between normal fault slip and erosion on relief evolution: Insights from experimental modelling. Tectonophysics, 2011, 513, pp.1-19. 10.1016/j.tecto.2011.10.005 . hal-00646966

\section{HAL Id: hal-00646966 https://hal.science/hal-00646966}

Submitted on 1 Dec 2011

HAL is a multi-disciplinary open access archive for the deposit and dissemination of scientific research documents, whether they are published or not. The documents may come from teaching and research institutions in France or abroad, or from public or private research centers.
L'archive ouverte pluridisciplinaire HAL, est destinée au dépôt et à la diffusion de documents scientifiques de niveau recherche, publiés ou non, émanant des établissements d'enseignement et de recherche français ou étrangers, des laboratoires publics ou privés. 


\title{
Accepted Manuscript
}

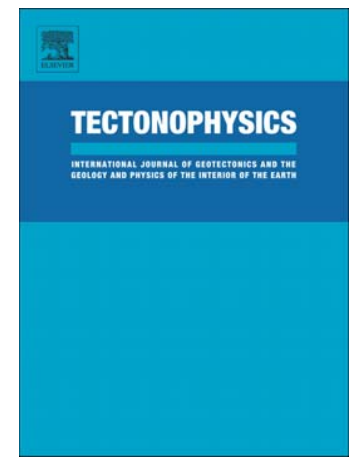

Interaction between normal fault slip and erosion on relief evolution: Insights from experimental modelling

\author{
V. Strak, S. Dominguez, C. Petit, B. Meyer, N. Loget \\ PII: $\quad$ S0040-1951(11)00411-2 \\ DOI: $\quad$ doi: $10.1016 /$ j.tecto.2011.10.005 \\ Reference: $\quad$ TECTO 125253
}

To appear in: $\quad$ Tectonophysics

Received date: $\quad 23$ March 2011

Revised date: $\quad 20$ September 2011

Accepted date: $\quad 8$ October 2011

Please cite this article as: Strak, V., Dominguez, S., Petit, C., Meyer, B., Loget, N., Interaction between normal fault slip and erosion on relief evolution: Insights from experimental modelling, Tectonophysics (2011), doi: 10.1016/j.tecto.2011.10.005

This is a PDF file of an unedited manuscript that has been accepted for publication. As a service to our customers we are providing this early version of the manuscript. The manuscript will undergo copyediting, typesetting, and review of the resulting proof before it is published in its final form. Please note that during the production process errors may be discovered which could affect the content, and all legal disclaimers that apply to the journal pertain. 


\title{
Interaction between normal fault slip and erosion on relief evolution: Insights from experimental modelling
}

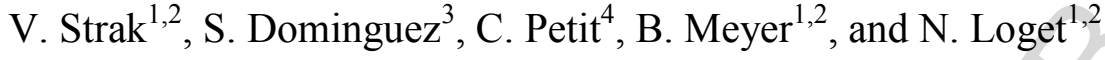 \\ ${ }^{1}$ UPMC Univ Paris 06, UMR 7193, ISTeP, F-75005, Paris, France \\ ${ }^{2}$ CNRS, UMR 7193, ISTeP, F-75005, Paris, France \\ ${ }^{3}$ University of Montpellier, UMR 5243, Géosciences Montpellier, UM2, CNRS, F-34095, \\ Montpellier, France \\ ${ }^{4}$ University of Nice, UMR 6526, GéoAzur, CNRS, F-06230, Villefranche Sur Mer, France \\ Contact: vincent.strak@upmc.fr
}

\begin{abstract}
The growth of relief in active tectonic areas is mainly controlled by the interactions between tectonics and surface processes (erosion and sedimentation). The study of long-lived morphologic markers formed by these interactions can help quantifying the competing effects of tectonics, erosion and sedimentation. In regions experiencing active extension, river-long profiles and faceted spurs (triangular facets) can help understanding the development of mountainous topography along normal fault scarps. In this study, we developed analogue experiments that simulate the morphologic evolution of a mountain range bounded by a normal fault. This paper focuses on the effect of the fault slip rate on the morphologic evolution of the footwall by performing three analogue experiments with different fault slip rates under a constant rainfall rate. A morphometric analysis of the modelled catchments allows comparing with a natural case (Tunka half-graben, Siberia). After a certain amount of fault slip, the modelled footwall topographies of our models reaches a dynamic equilibrium
\end{abstract}


(i.e., erosion balances tectonic uplift relative to the baselevel) close to the fault, whereas the topography farther from the fault is still being dissected due to regressive erosion. We show that the rates of vertical erosion in the area where dynamic equilibrium is reached and the rate of regressive erosion are linearly correlated with the fault throw rate. Facet morphology seems to depend on the fault slip rate except for the fastest experiment where faceted spurs are degraded due to mass wasting. A stream-power law is computed for the area wherein rivers reach a topographic equilibrium. We show that the erosionnal capacity of the system depends on the fault slip rate. Finally, our results demonstrate the possibility of preserving convex river-long profiles on the long-term under steady external (tectonic uplift and rainfall) conditions.

\section{Introduction}

In tectonically active settings, interactions between crustal deformation and surface processes related to climate control the growth of relief in space and time (e.g., Beaumont et al., 1992; Willett, 1999; Burbank and Anderson, 2001; Pelletier et al., 2010). As shown by several studies (e.g., Hack, 1960; Avouac and Burov, 1996, Roe et al., 2006), after a transitional phase of relief maturation, tectonic uplift and erosion tend to balance each other and relief morphology reaches a topographic equilibrium. Despite the destructive effect of erosion, some morphological markers, such as uplifted erosionnal or alluvial surfaces, are preserved and reflect the competing effects of erosion and tectonics (e.g., Avouac, 2003; Roe et al., 2006). However, most of these markers record the deformation over a few hundreds of ka that does not allow assessing the long-term relief evolution (several Ma). The analysis of long-lived topographic markers is therefore needed to provide quantitative data to better constrain the competition between tectonics and erosion on the long-term. Amongst these markers, faceted spurs (or triangular facets) are frequently observed along active faults and 
are typically associated with normal fault scarps (e.g., Davis, 1903; Cotton, 1950; Birot, 1958; Burbank and Anderson, 2001). More rarely, they can form also along active fold limbs where they are associated with fold scarp formation (e.g., Hubert-Ferrari et al., 2007). In extensional contexts, faceted spurs develop in response to progressive subsidence of the hanging-wall and uplift of the footwall coeval with incision by fault-perpendicular drains (Figure 1). Their shape seems controlled by the progressive exhumation of the fault plane which is then submitted to surface erosion processes (e.g., Wallace, 1978; Petit et al., 2009a). Triangular facets are observed all over the world throughout various lithologies, climates and fault slip rates like in the Basin and Range (e.g., Davis, 1903; Hamblin, 1976; Wallace, 1978; Ellis et al., 1999; Depolo and Anderson, 2000; Zuchiewicz and McCalpin, 2000; Densmore et al., 2004), in the Baikal rift (e.g., San'kov et al., 2000; Petit et al., 2009b), in the Aegean region (e.g., Armijo et al., 1991, 1996; Meyer et al., 2002; Ganas et al., 2005), in Tibet (e.g., Armijo et al., 1986; Mahéo et al., 2007), in New-Caledonia (e.g., Lagabrielle and Chauvet, 2008) and in the Pyrenees (e.g., Carozza and Baize, 2004). Exceptions arise in very dry areas, like the Afars, or for very low throw rates (e.g., DePolo and Anderson, 2000) where faceted spurs do not develop or are not preserved. River-long profiles are other interesting markers of active fault dynamics. Many studies have shown that in the case of a transient tectonic or eustatic stage, river-long profiles evolve from a concave shape to a convex one with a more or less pronounced knickpoint (e.g., Cowie et al., 2006; Loget et al., 2006; Harkins et al., 2007; Whittaker et al., 2008; Valla et al., 2010). The evolution of river-long profiles is often investigated by the analysis and the correlation of fluvial terrace levels (e.g., Merritts et al., 1994). However, their poor preservation over more than hundred of ka makes difficult to study the long-term relief.

Understanding how the morphological markers form, evolve, and record deformation may nonetheless help constraining active deformation kinematics and climate variability (e.g., 
Burchfiel et al., 1999; Montgomery et al., 2001). In this perspective, numerical or experimental approaches can be useful to study the evolution of the morphology. For example, considering numerical models using common incision laws, Petit et al. (2009a and 2009b) demonstrate that, for a given rainfall, linear relationships can be established to link facet slope, facet height and fault throw rate. However, the stream power law (e.g., Howard et al., 1994; Whipple and Tucker, 1999) used in these models to generate river incision is more adapted to large-scale reliefs than to small-scale active tectonic settings where other processes like landslides, debris flow or hillslope processes contribute to the evolution of the relief (Densmore et al., 1998).

Complementary insights on how active tectonics and erosion laws interact can be also provided experimentally. In analogue models, erosion, transport and sedimentation processes are triggered by spraying water micro-droplets on a specific water-saturated analogue granular material. This approach has been extensively used to study the interactions between tectonics, erosion and sedimentation (e.g., Hasbargen and Paola, 2000; Pelletier, 2003; Bonnet and Crave, 2003, 2006; Lague et al., 2003; Babault et al., 2005; Niemann and Hasbargen, 2005; Graveleau and Dominguez, 2008; Bonnet, 2009; Paola et al., 2009 for a thorough review). In most studies, tectonics was simulated by an overall constant uplift rate equivalent to long wavelength regional uplift or base level subsidence. Graveleau and Dominguez (2008) introduced more realistic deformation mechanisms allowing for thrust fault formation to study the evolution of active foreland morphology, hence allowing differential uplift and deformation propagation.

In this paper, we present the results of explorative experimental modelling, based on the experimental protocol of Graveleau and Dominguez (2008) applied to the study of active normal faults. Our objectives are to document quantitatively the morphometric evolution of a normal fault escarpment and investigate, for a given rainfall rate, the impact of different fault 
slip rates on the morphologic evolution of the models as well as on the couplings between erosion and tectonics.

\section{Methodology}

\subsection{Experimental set-up and boundary conditions}

The experimental set-up is adapted from Graveleau and Dominguez (2008). It is composed of a deformation device, a rainfall system and a laser interferometer used to monitor the topography of the model through time (Figure 2). The deformation device is composed of two plates (total size $130 \times 100 \mathrm{~cm}$ ) representing the footwall and the hangingwall of a normal fault (size $100 \times 60 \mathrm{~cm}$ and $100 \times 70 \mathrm{~cm}$, respectively). The footwall (upper plate) is maintained fixed while the hanging-wall (lower plate) can move along a predetermined normal fault plane that separates the two plates. Due to technical constrains, the maximum fault slip is limited to $10 \mathrm{~cm}$. This simple configuration has been tested and improved to better simulate the hanging-wall subsidence and river base level drop. Consequently, we adapt on the mobile plate a flexural tray to simulate the downward tectonic flexure of the hanging-wall (e.g., Armijo et al., 1986; Figure 2). In terms of boundary conditions, this configuration is more realistic than a simple horizontal plate subsiding uniformly but requires an additional scaling to constrain the flexural deformation of the hanging-wall basement through time (buckling/bending and wavelength, see section 2.3.). The boundary that separates the two plates dips at $60^{\circ}$ and controls the dip of the fault plane where propagating throughout the analogue material toward the surface. The slip rate and azimuth of slip are controlled using two computerised stepping motors linked to perpendicular linear guideways ensuring an accurate control on the fault kinematics. In this paper, we simulate a continuous dip slip normal fault displacement. The rainfall system is made up of 4 sprinklers that diffuse water micro-droplets homogeneously $(26 \pm 4 \mathrm{~mm} / \mathrm{h})$ over 
the footwall and the hanging-wall plate (the subsiding basin). The data acquisition system is composed of a laser interferometer coupled to CCD cameras to measure the topography of the model and to record morphology evolution. The laser interferometer provides Digital Elevation Models (DEMs) at different key stages of the experiment with a spatial resolution of $0.5 \mathrm{~mm}$ and a precision better than $1 \mathrm{~mm} \mathrm{rms}$. During data acquisition (about 15 minutes), tectonics and rainfall are stopped.

\subsection{Analogue material}

The analogue material used in our experiments to model natural rocks is directly derived from the wet granular mixture used by Graveleau and Dominguez (2008) and Graveleau et al. (accepted) to model tectonic-erosion coupling in an active foreland. However, to improve the modelled morphology and especially to enhance hillslope diffusion versus river incision, slight modifications in material composition were made (Table 1), resulting in slight modifications of its physical parameters. The new analogue material is made of glass microbeads (40\%), silica powder $(35 \%)$, plastic (PVC) powder $(23 \%)$ and graphite powder $(2 \%)$. The use of a PVC powder with a smaller grain size decreases the bulk granulometry of the mixture and increases the distances for transport of river sediments. The increase of the proportion of the PVC powder and the decrease of that of the silica powder allow decreasing the cohesion of the material in order to better simulate the behaviour of rivers at small scale. Indeed, a decrease in material cohesion yields an increase in the transport capacity of rivers, in turn related to an increase of hillslope processes. The physical parameters of this new granular mixture were measured using dedicated devices available at Geosciences Montpellier laboratory. Amongst those, we used a modified Hubbert-type direct shear apparatus (Graveleau et al., accepted; see their figure 5) to measure internal friction and cohesion of dry and wet granular materials. Measurements were made using a water 
saturation of $20+/-1 \%$ which is the average water saturation of the analogue material under the experimental conditions. Internal friction coefficient, cohesion, density and median grain size of the analogue material are respectively: $\varphi=35+/-2^{\circ}, \mathrm{C}=600+/-100 \mathrm{~Pa}, \mathrm{~d}=1.6+/-0.1$ $\mathrm{g} / \mathrm{cm}^{3}, \mathrm{D}_{50}=80+/-5 \mu \mathrm{m}$. Erodability properties of the analogue material are close to those of the mixture used by Graveleau and Dominguez (2008), despite a slight increase of the erodability due to the slight decrease in cohesion, as previously discussed.

\subsection{Scaling of experiments}

Previous works have shown that a reasonable scaling can be achieved considering several proportionality ratios between model and nature parameters (e.g., Hubbert, 1937, 1951; Horsfield, 1977; Shemenda, 1983; Richard, 1991; Davy and Cobbold, 1991; Cobbold and Jackson, 1992). Accordingly, an analogue model is properly scaled if it respects geometric, kinematic and dynamic similarity criteria. Since inertial forces can be neglected in nature and in our experiments, and considering that natural rocks and granular analogue materials deform according to the Mohr-Coulomb failure criterion, the similarity criteria to be considered are :

$$
\begin{aligned}
& L^{*}=L m / L n \quad \text { for the geometric criterion } \\
& S^{*}=C^{*}=d^{*} \cdot g^{*} \cdot L^{*} \quad \text { for the dynamic criterion }
\end{aligned}
$$

$L^{*}, S^{*}, C^{*}, d^{*}, g^{*}$ are model to nature ratios for length, stress, cohesion, density and gravity respectively. $L m$ and $L n$ are characteristic lengths in models and in nature, respectively. For natural rocks, internal friction and cohesion values range between $20-40^{\circ}$ and 5-180 $\mathrm{MPa}$, respectively (Byerlee, 1978; Lama and Vutukuri, 1978). Note that according to the scaling theory, the internal friction coefficient of the analogue material should be equivalent to those of natural rock. Considering the physical and mechanical properties of the analogue material (see 2.2 ), a mean natural rock density of $\sim 2500 \mathrm{~kg} / \mathrm{m}^{3}$, a mean natural rock cohesion of $\sim 40$ 
MPa and using equations 1 and 2, we estimate a mean length ratio of $L^{*}=2.10^{-5}$, so $1 \mathrm{~cm}$ in the model represents $500 \mathrm{~m}$ in nature. This ratio is close to the value estimated by Graveleau et al. (accepted) but should be nonetheless used with caution considering the limits of the scaling theory and the uncertainties on natural rocks and analogue material physical parameters. However, we consider that the scaling method described above allows for a first order estimation of the model to nature spatial ratio good enough to extrapolate experimental quantitative results to nature.

As mentioned by Paola et al. (2009), a fully dynamical scaling in morphodynamic experiments is elusive. According to the dynamic criterion, the fluid used in the experiments (i.e., water) has a too high kinematic viscosity to be compatible with the Reynolds dimensionless variable. Indeed, Reynolds number measured in natural rivers is high $(\mathrm{Re}>$ $10^{6}$; Malverti et al., 2008), indicating that turbulent behaviour is dominant whereas it is low in analogue models ( $\operatorname{Re}<500$; Graveleau et al., accepted), indicating a laminar behaviour. However, the other dimensionless variable, the Froude number, is not affected by this discrepancy and appears to be equivalent in nature and in analogue models (from 0.2 to 0.6 and from 0.01 to 1 , respectively). This indicates that the ratio between gravitational forces and viscous and inertial forces is respected (e.g., Niemann and Hasbargen, 2005). As noticed by Malverti et al. (2008), laminar and turbulent flows in analogue experiments give river-long profiles that are governed by identical dimensionless equations and therefore follow the same dynamics. Thus, we consider that the long-term dynamics/behaviour of natural rivers is well simulated in our analogue experiments.

Evaluating time scaling is a difficult task because the morpho-tectonic processes (e.g., fault slip, fluvial incision, sediment transport and hillslope processes) that shape natural and modelled topographies occur over several orders of velocities. This feature complicates the determination of dimensioning equations compatible with all these processes. Achievable 
time scaling requires also to neglect inertial forces, which would not be possible if we aimed at reproducing the short-term behaviour of natural fluid flows. In our experiments, fluid flows locally produce small accelerations which can be neglected because their impact on the topography is weak. Moreover, considering the large time span of landscape evolution which we seek at reproducing and the spatial scaling of our models, we can assume that water and eroded sediments in nature are routed down at an almost constant velocity in a laminar flow. Therefore, accelerations are small enough to neglect inertial forces. Finally, model rheology cannot help constraining the time scaling because the mechanical properties of the analogue material (Mohr-Coulomb mechanical behaviour) can be considered as time-independent under our experimental protocol.

Based on these considerations, we propose a simplified solution where time scaling can be reasonably estimated by comparing long-term erosion rates in the models and in nature. To achieve this goal, we use two similarity criteria that include time and velocity (e.g., Hubbert, 1937):

$$
T^{*}=T m / T n \quad \text { for the kinematic criterion }
$$

$$
V^{*}=V m / V n=\frac{L m / T m}{L n / T n}=L * / T^{*}
$$

for the similarity of velocities

$T^{\star}$ and $V^{*}$ are model to nature ratios for time and velocity, respectively. $T m$ and $T n$ are characteristic times in models and in nature, respectively. $V m$ and $V n$ are velocities in models and in nature, respectively. In our experiments, we measure catchment-averaged denudation rates ranging from 1.4 to $5.4 \pm 0.5 \mathrm{~mm} / \mathrm{h}$. In nature, catchment-averaged denudation rates on normal fault footwalls have been determined for the Weber and the Salt Lake City segments of the Wasatch fault (e.g., Stock et al., 2009) using cosmogenic radionuclide analysis. Stock 
et al. (2009) found a mean long-term denudation rate for all catchments of about $0.2 \mathrm{~mm} / \mathrm{yr}$, consistent with those obtained by Densmore et al. (2009) in a similar study in the Basin and Range and by Cowie et al. (2006) which use a numerical modelling approach scaled from an Apennine natural case. They are also in the same order than the long-term hillslope erosion rate found by Tucker et al. (2011) on facet slopes of the Magnola fault (Apennines). We use then the mean denudation rates for the Wasatch fault of $0.2 \mathrm{~mm} / \mathrm{yr}$ to compare with our experiments. Considering the length scaling calculated previously (see 2.2) and using the equation (4), we estimate that $1 \mathrm{~s}$ in the model is equivalent to 65 to 375 years in nature. Keeping in mind the difficulty of a fully dynamical scaling, we arbitrarily assume that $1 \mathrm{~s}$ equals 200 years. Thus, the topography of the experiments would approximate natural longterm landscapes ranging between 1,5 Myr and $6 \mathrm{Myr}$ well within the known ages of mature normal fault systems. Finally, to constrain the geometry and the kinematics of the hangingwall flexure, we used both available numerical models and natural examples (e.g., King et al., 1988; Stein et al., 1988) and the well-documented geometry of the flexure of the Xylokastro fault in the Corinth Rift (see figure 23 in Armijo et al., 1996).

\subsection{Experimental dataset}

We performed three experiments with fault slip rates of 3, 6 and $12 \mu \mathrm{m} / \mathrm{s}$ (comparable to about $0.75,1.5$ and $3 \mathrm{~mm} / \mathrm{yr}$ in nature according to model scaling) and a constant rainfall rate of $26 \pm 4 \mathrm{~mm} / \mathrm{h}$ (in the lower range of rainfall rates used by Bonnet and Crave, 2003, 2006; Lague et al., 2003; Babault et al., 2005; Niemann and Hasbargen, 2005; Graveleau and Dominguez, 2008). 8 DEMs were computed for the 3 and $6 \mu \mathrm{m} / \mathrm{s}$ experiments and 4 for the $12 \mu \mathrm{m} / \mathrm{s}$ experiment. A DEM of the initial $1^{\circ}$ tilted flat surface is also acquired before onset of each experiment. The DEMs were acquired at similar values of fault slip (fault displacement) to facilitate comparisons between the three experiments (Table 2). For each experiment we 
first describe qualitatively the morphological evolution of the topography, focusing on the growth of the drainage network and faceted spurs. Second, we present a quantitative analysis of the DEMs to extract morphometric characteristics and quantities (slope and height of facets, local river slopes, drainage areas, amount of eroded material). We also attempt to evaluate the effects of incision and diffusion processes by quantifying the amount of eroded material along rivers and crests. For that purpose, instantaneous and finite erosion rates were approximated as the difference in the amount of erosion between two successive DEMs and between the initial and the final DEMs, divided by the corresponding time span, respectively.

\section{Results}

The modelled landscapes succeed in developing the main morphological features commonly observed along normal fault scarps: faceted spurs, drainage basins and alluvial fans. To evaluate the degree of morphological similarities between our models and natural landscapes, we first analysed qualitatively relief evolution, then, we determined quantitatively the geometric relationships that characterise the different morphological features.

\subsection{Evolution of morphology}

The three models share the same general morphological evolution. The hydrographic network first develops along the fault trace as dense fault-perpendicular gullies. This incipient drainage network rapidly connects to a main fault-parallel drainage running on the subsiding hanging-wall (Figure 3 and 4). The position of the fault-parallel drainage is controlled by the subsidence of the material overlying the flexural tray and by the position of the lateral outlets of the model. This defines the local river base level which controls footwall river incision during the experiment. On the footwall, regressive erosion associated to river incision digs fault-perpendicular valleys separated by intervening parallel topographic ridges. Close to the 
fault trace, each crest line splits into two oblique crests (i.e., the facet edges) trending a few tens of degrees $\left(20^{\circ}\right.$ on average) apart from the main crest line direction. They delimit a triangular facet which geometry evolves during the experiment. The surface of the triangular facets is progressively carved by hillslope processes inducing a rapid erosion of the exhumed fault plane. Consequently, triangular facets in our models do not display a typical convex shape but rather a concave one. Despite significant erosion of the facets, their edges are sufficiently preserved during the experiments so the evolution of faceted spur geometries can be tracked. The dissection of the initial flat topography spreads progressively upstream while alluvial fans develop downstream in response to flexural subsidence (Figures 3 and 4). The topography evolves from small and narrow catchments localised atop the fault scarp to wider catchments propagating upstream on the initial flat surface (Figure 4). At the beginning of the experiments, small trapezoidal facets grow in response to incision occurring in small catchments. At the same time, sorted particles are deposited in growing alluvial fans downstream the fault. The small drainage basins progressively merge in response to regressive erosion, inducing a decrease in the number of facets, fault-perpendicular crest lines and catchments. In the next stage, once a stable number of facets and catchments is reached (typically 6 to 8 ), the evolution of the morphology is dominated by the elongation of the faultperpendicular drains and the subsequent incision of the upstream relief which becomes more dissected. The alluvial fans prograde on the hanging-wall inducing the migration of the faultparallel river and defining the local base level away from the fault trace.

Comparing the final stages of the three experiments, several morphological differences can be evidenced (Figure 5). First, for the $3 \mu \mathrm{m} / \mathrm{s}$ experiment, the length of the main drains is significantly longer because regressive erosion has more time to propagate upfault when the fault slip rate is slow. Mean values of headward erosion rates are $0.012,0.022$ and $0.04 \mathrm{~mm} / \mathrm{s}$ for the slowest to the fastest experiment. Thus, the higher the fault slip rate, the faster the 
headward erosion rate. This first-order difference indicates that tectonic and erosion rates are closely coupled because the ratio between this migration retreat rate and the throw rate is constant $(4+/-0.25)$ whatever the slip rate. Second, the relief along the fault scarp is less well preserved for the fastest experiment. For this experiment, the drainage network is not sufficiently developed to provide enough sediment required to fill the hanging-wall basin, and then to maintain reasonable slopes in the footwall. Consequently, mass wasting is enhanced at the scarp front preventing a good preservation of faceted spurs. Third and by contrast, the relief displays smaller details for the slowest experiment because for a given fault slip, the amount of rainfall is more important. Finally, the regional slope (i.e., the model long wavelength topographic gradient) is higher when the fault slip rate is faster.

\subsection{Quantitative analysis}

\subsubsection{Measurements}

For each experiment, fault-perpendicular topographic profiles were extracted from the DEMs and compared to erosionless theoretical topographic profiles (Figure 6). We analysed topographic profiles running either along river beds, along facet edges or cutting the facets in the middle to extract facet heights $\left(\mathrm{H}_{\mathrm{f}}\right)$, averaged facet slopes $\left(\mathrm{S}_{\mathrm{f}}\right)$ and local river slopes $\left(\mathrm{S}_{\mathrm{r}}\right)$ (Figure 3c and 6). We also plotted fault-parallel topographic profiles at several distances from the fault to quantify the amount of eroded material along rivers $\left(\mathrm{HR}_{\mathrm{r}}\right)$ and crests $\left(\mathrm{HR}_{\mathrm{c}}\right)$. We also extracted the upstream drainage area (A), the upstream length (L) and the local slope along the main channels $\left(\mathrm{S}_{\mathrm{r}}\right)$. We first studied footwall topographic evolution throughout different morphological characteristics (i.e., hypsometry, river-long profiles, slope-area relationship, morphometric characteristics of faceted spurs). Second, we investigated how normal fault slip influences the rates of erosion in the footwall for the three experiments performed with different fault slip rates. 


\subsubsection{Drainage basins morphometric analysis}

Similarities with natural field data are analysed using ASTER satellite DEMs of the Tunka half-graben (South-west of the Baikal Rift) using the Rivertools ${ }^{\circledR}$ software. ASTER DEMs have a spatial resolution of $30 \mathrm{~m}$ and a vertical precision of about $15 \mathrm{~m}$, good enough to measure the geometry of the faceted spurs that develop along the North-Tunka active normal fault. The cumulated throw is about 5000 to $5600 \mathrm{~m}$ and the average geological throw rate of about $0.2 \mathrm{~mm} / \mathrm{yr}$ (McCalpin and Khromovskikh, 1995; Larroque et al., 2001; Arjannikova et al., 2004). We also compare our results with other natural cases available in the literature (e.g., Hurtrez et al., 1999; Snyder et al., 2000) and with analogue models (Lague et al., 2003; Bonnet and Crave, 2006).

Hack's law (Hack, 1957) is a well known morphometric benchmark that defines the relationship between main river length and upstream drainage area. For all the DEMs extracted from the three experiments, the same power law fits the data stemming from all the drainage basins (Figure 7). It is thus independent of the fault slip rate, as already proposed by Montgomery and Dietrich (1992) and Hurtrez et al. (1999) using field data. In our experiments, the Hack exponent is of 0.48 , which is close to the value of 0.49 computed in experiments by Lague et al. (2003). It is also in the range of values obtained for natural basins (e.g., Hack, 1957; Montgomery and Dietrich, 1992), including the value of 0.52 for the Tunka mountain range (Figure $7 \mathrm{~b}$ ). This analysis indicates that models are characterized by a drainage network organisation comparable to nature.

We derived hypsometric curves for all the drainage basins of the modelled footwalls using each extracted DEM (Figure 8a). The hypsometric curve represents the relative proportion of the model surface situated above/below a given height (Strahler, 1952). It has been shown that active reliefs typically display a S-shaped hypsometric curve with a high 
hypsometric integral (i.e., the area below the curve) whereas it is more concave with a lower integral for reliefs in declining equilibrium (e.g., Willgoose, 1994; Hurtrez et al., 1999). All our experiments display a convex hypsometric curve pointing to the large proportion of high elevations due to the preservation of the initial plateau. Comparing with the footwall of the Tunka mountain range, the hypsometric curve is more S-shaped and has a lower normalized integral than that for the experiments. Through time, the experimental curves remain convex for the 3,6 and $12 \mu \mathrm{m} / \mathrm{s}$ experiments up to 7200,14400 and $21600 \mathrm{~s}$ respectively, because the main river heads are continuously migrating toward the boundary of the sandbox, and are then permanently rejuvenated. For the $3 \mu \mathrm{m} / \mathrm{s}$ experiment at a more advanced time (28800 s), the hypsometric curve becomes more S-shaped and comparable to the Tunka natural case. This indicates that the drainage network is more mature due to the entire dissection of the plateau. For a given fault slip (45.6 and $91.3 \mathrm{~mm}$ ) and consequently for three different times, the longer the time the more dissected the topography (Figure 8b). As anticipated, an important parameter that controls the dissection of the relief is the duration of rainfall. For a given time (7200 and $14400 \mathrm{~s}$ ) and consequently for three different fault slips, the faster the fault slip rate the more dissected the topography (Figure 8c). Another important parameter that controls the dissection of the relief is the fault slip rate. However, one can notice that the curves of the 3 and $6 \mu \mathrm{m} / \mathrm{s}$ experiments at $7200 \mathrm{~s}$ are very close while they diverge at $14400 \mathrm{~s}$. These results likely show a threshold effect of the topographic gradient, which becomes apparent between the fault slips 45.6 and $91.3 \mathrm{~mm}$.

In our analogue models, river-long profiles typically exhibit a convex shape (Figure 9). This is also the case for the main rivers of the Tunka mountain front (Figure 9c,d), except at channel heads where the river-long profiles become concave. This slight difference with nature is due to the initial planar surface and to the lack of a fault-parallel drainage divide on the model footwall. Indeed, the main river heads are permanently migrating toward the 
boundary of the sandbox and thus, are permanently rejuvenating while in the field example, they are fixed because they have reached the drainage divide. The evolution of river-parallel topographic cross-sections displays a progressive base level fall when the altitude reference point is on the top of the footwall (Figure 10a). The base level corresponds to the position of the fault-parallel river in the hanging-wall (Figure 6). When the relative altitude of the base level is fixed, the evolution of these profiles shows that a topographic equilibrium is reached for the last DEMs up to about $10 \mathrm{~cm}$ upfault (Figure 10b). Therefore, in this area, erosion and tectonics balance each other in riverbeds.

Finally, we analysed the relationship between local river slope and upstream drainage area (e.g., Hack, 1957; Snyder et al, 2000; Montgomery, 2001; Lague et al., 2003). In our experiments, this correlation is linear (Figure 11) due to the convexity of river-long profiles, whereas a power-law relationship is observed in many different geologic settings (e.g., Hack, 1957; Snyder et al., 2000 and references therein) and in the experiments performed by Lague et al. (2003) and Bonnet and Crave (2006). Moreover, the slope-area relationship computed for our models is inverted (slope increases with upstream drainage area) compared to that predicted with the stream power law (Montgomery, 2001). Comparing the slope-area relationship between the three models, we observe that it is dependent on the fault slip rate. Indeed, both slope and Y-intercept of the linear correlations increase with the fault slip rate. This effect is also described in natural settings (Snyder et al., 2000) and in experimental modelling (Lague et al., 2003). This observation that highlights the impact of the fault slip rate on the river bed slope will be discussed further (3.2.5).

\subsubsection{Faceted spurs morphometric evolution}

To study the morphometric evolution of faceted spurs through time we analyze the relationships between their geometry (slope and height) and the fault slip for the three 
experiments (Figure 12). Mean facet slope $\left(S_{\mathrm{f}}\right)$ increases at the beginning of the $6 \mu \mathrm{m} / \mathrm{s}$ experiment and remains stable (around $22^{\circ}$ ) after a cumulated fault slip of $45.6 \mathrm{~mm}$ (Figure 12a). For the two other experiments, the mean facet slope reaches equilibrium values of $17^{\circ}$ and $22^{\circ}$ for the $3 \mu \mathrm{m} / \mathrm{s}$ and $12 \mu \mathrm{m} / \mathrm{s}$ experiments, respectively. Facet slope appears to scale with fault slip rate for the $3 \mu \mathrm{m} / \mathrm{s}$ and $6 \mu \mathrm{m} / \mathrm{s}$ experiments. This is not the case for the $12 \mu \mathrm{m} / \mathrm{s}$ experiment, which displays mean slopes close to that of the $6 \mu \mathrm{m} / \mathrm{s}$ experiment. This is due either to enhanced erosion (hillslope processes and mass wasting) possibly triggered under such a rapid fault slip rate or to the threshold slope from which hillslope processes are activated (Montgomery, 2001).

Mean facet height $\left(\mathrm{H}_{\mathrm{f}}\right)$ appears to be proportional to the cumulated fault slip (Figure 12b). For the slowest experiment, facet height increases at the beginning of the experiment, and stabilizes at about $18 \mathrm{~mm}$. Facet height reaches $28 \mathrm{~mm}$ at the end of the $6 \mu \mathrm{m} / \mathrm{s}$ experiment. The apparent stabilization of the facet height at the end of this experiment suggests that the value of $28 \mathrm{~mm}$ is close to the steady-state value. Here again the $12 \mu \mathrm{m} / \mathrm{s}$ experiment displays a different behaviour with smaller facets. For this experiment, because the fault scarp undergoes strong erosion, it is difficult to seek for a precise relationship between fault slip rate and facet height or slope. The stabilization of the facet height at the end of the experiments indicates that, for a given distance from the fault, the erosion rate in the rivers equals the erosion rate on the crests. Indeed, the height between the summit of a crest and the riverbed remains constant and indicates that a local equilibrium is reached.

\subsubsection{Effect of fault slip rate on erosion}

We compute, for the mains drains and along the crests, the averaged erosion rates cumulated over the whole experiment and the averaged erosion rates between two successive DEMs. The former corresponds to the height of removed material since the beginning of the 
experiment (HR) divided by the total time $\mathrm{T}$ (Figure 6). It is equivalent to erosion rates averaged over large time spans as often measured in the field. The latter is defined as the height of removed material between two successive DEMs $(\triangle \mathrm{HR})$ divided by the corresponding time span $(\Delta \mathrm{t})$. It may be considered as an approximation of the instantaneous erosion rate. We analyze these measurements at several distances from the fault trace along the main drains and along the crests which correspond to the facets edges.

At the beginning of the experiments, at $20 \mathrm{~mm}$ upfault (Figure 13a,b), the erosion rate increases rapidly in the drains to reach a constant value, while it appears to be delayed upstream (up to 20-40 mm fault slip) due to the propagation of regressive erosion (Figure $13 \mathrm{c}, \mathrm{d})$. Erosion on the crests is delayed compared to erosion in the drains but once initiated, it reaches rapidly a comparable value. This observation suggests that the river dynamics (river bed incision) controls the hillslope processes, which in turn govern the evolution of the crests. As already suggested by the stability of the facet height during the last stages of the $3 \mu \mathrm{m} / \mathrm{s}$ experiment (right part of the green curve on Figure 12b), the erosion rates in the drains and on the crests become identical up to $80 \mathrm{~mm}$ upstream from the fault (right part of the blue and green curves on Figure 13b,d). We thus infer that, at this stage, the interactions between tectonics, hillslope and river processes have reached dynamic equilibrium (or a steady state) up to $80 \mathrm{~mm}$ upfault. This agrees with the equilibrium profile of rivers observed for the latest stages of the experiments up to $100 \mathrm{~mm}$ (Figure 10). This equilibrium is reached for the 3 $\mu \mathrm{m} / \mathrm{s}$ and $6 \mu \mathrm{m} / \mathrm{s}$ experiments but it is less obvious for the $12 \mu \mathrm{m} / \mathrm{s}$ one where $\Delta \mathrm{HR} / \Delta \mathrm{t}$ along the crests is higher than $\Delta \mathrm{HR} / \Delta \mathrm{t}$ along the drains at the final stages (Figure 13b,d). This is again related to the drastic erosion of the mountain front that characterizes this experiment. Finally, the most outstanding result is that erosion increases with fault slip rate. This allows determining a constant ratio of $0.35+/-0.02$ between erosion rate $(\mathrm{mm} / \mathrm{s})$ and fault throw rate $(\mathrm{mm} / \mathrm{s}) 20 \mathrm{~mm}$ upstream from the fault. This reflects the relative height of the footwall 
submitted to erosion due to the dynamics of the sedimentary basin (i.e., due to the base-level dynamics). When examining the relationship between the averaged erosion rate and the distance upstream from the fault (Figure 14), a linear correlation is evidenced for the drains. Both slope and Y-intercept of the linear correlations increase with the fault slip rate. The slope of the linear correlations characterizes the long-term topographic gradient of the footwall, which is higher when the fault slip rate is faster. The Y-intercept represents the long-term erosion rate close to the fault, which is linked to the fault slip rate. Along the crests, HR/T decreases rapidly upfault to zero where the crests merge with the pristine plateau (Figure 14), progressively dissected in response to regressive erosion.

These results demonstrate that erosion rate in the drains depends closely on the fault slip rate and influences hillslope processes and the overall morphology of the model.

\subsubsection{Link between local slope, drainage area, erosion rate and fault slip rate}

To evaluate the influence of the local slope and the drainage area on the incision rate, we compute relationships between measured river erosion rates versus upstream drainage area (A) and versus local river slope $(S)$ respectively (Figures $15 \mathrm{a}, \mathrm{b})$. The variables can be adjusted by a power law relationship.

Generic incision laws used in numerical models include local river slopes $S$ and upstream drainage area $A$, which are linked to the incision rate (e.g., Howard et al., 1994; Whipple and Tucker, 1999). The incision rate law, also called stream power law is of the form:

$$
E=K \cdot A^{m} \cdot S^{n}
$$

where $K$ is a dimensional coefficient of erosion and where the exponents $m$ and $n$ depend on global climate parameters. We aim at examining this empirical relationship in the light of our experimental results (Figure 15c). We are aware that our models do not reach a global steadystate everywhere, in particular for the 6 and $12 \mu \mathrm{m} / \mathrm{s}$ experiments where the pristine plateau is 
not entirely dissected. However, a local steady state is reached in the rivers for the three experiments up to $10 \mathrm{~cm}$ upfault. By computing best fitting laws for relationships between measured river erosion rates versus $A \times S$ (Figure 15c), we observe that the stream power law is respected with $m=n=1$. Indeed, in each experiment the incision rate is a linear function of the stream power, with a linear coefficient linked to the fault slip rate (Figure 15c). As for the slope-area relationship, the positive correlation between incision rate and fault slip rate is related to a general increase in mean river slopes with increasing fault velocity. The slope coefficient relating the incision rate to the $A \times S$ product ( $K$ in equation 5) increases with the fault slip rate (Figure 15d) following an empirically determined relationship such as:

$$
K=a \cdot V \cdot \exp (b)
$$

Where $V$ is the fault slip rate, and $a$ and $b$ are equal to $2.10^{-7}$ and 128 , respectively.

If sediments where not deposited in the piedmont, the ratio between incision and tectonic uplift (throw) on the long-term would equal 1 close to the fault. In our experiments, the ratio between the incision rate near the fault and the throw rate closes to $0.42+/-0.04$. This is due to the aggradation downfault (hanging-wall basin) which suggests that the sedimentation fills approximately $3 / 5$ of the vertical space created by the fault kinematics. This result suggests that piedmont sedimentation plays a major role in the dynamic evolution of the footwall because it reduces the tectonic uplift by modifying the elevation of the base level (Babault et al., 2005).

\section{Discussion}

\subsection{Couplings between slip rate and erosion rates}

Our results evidence important couplings between the fault slip rate and the morphodynamics of the model. 
We first highlight a linear relationship between the throw rate and the regressive erosion rate (headward erosion rate, Figure 5), a point that could be tested in natural settings.

Moreover, our models indicate a strong control of the fault throw rate on the vertical erosion rate (Figures 13 and 14). Rivers respond quickly to tectonic perturbations, dissecting the relief until reaching a stable incision rate balancing the relative tectonic uplift. After some time, river incision triggers the activation of hillslope processes which tend to equilibrate with the river incision rate to maintain a constant slope (around $20^{\circ}$ on average).

\subsection{The preservation of long-term convex river-long profiles}

An unexpected result is the preservation of the convex shape of experimental riverlong profiles (Figure 11). It is classically admitted that when river incision balances tectonic uplift, river-long profiles exhibit a concave shape (e.g., Hack, 1957; Sklar and Dietrich, 1998; Stock and Montgomery, 1999; Snyder et al., 2000; Whipple, 2001). This concavity can be explained by derivating erosion-transport laws of current rivers and then introduced in numerical models (e.g., Howard et al., 1994; Whipple and Tucker, 1999). However, some natural rivers display a convex longitudinal profile either in relation with an acceleration of the uplift rate or with a sudden drop of the base level (e.g., Cowie et al., 2006; Loget et al., 2006; Harkins et al., 2007; Whittaker et al., 2008; Valla et al., 2010). In normal faulting settings, many studies seem to indicate that this convex shape can persist over long time periods (> 1 Ma; e.g., Cowie et al., 2006; Whittaker et al., 2008) whereas theoretical landscape response times indicate that steady-state should be reached (e.g., Whipple, 2001). This might be a key point to better understand whether convex river-long profiles document changes in tectonic rate or a dynamic equilibrium between erosionnal and tectonic processes at a constant uplift rate. 
Although our experimental protocol does not allow us to reach a global dynamic equilibrium of the landscape, our results indicate that a constant fault throw rate can produce long-lived convex river-long profiles. Several hypotheses could explain this observation:

- Experimental conditions may influence erosionnal processes that control river-long profiles. In our experiments, self-sustaining rivers inducing local continuous incision do not develop due to rivers avulsion. However, this is also the case in other morpho-dynamic experiments (Lague et al., 2003; Paola et al., 2009 for a thorough review) where the concavity of the riverlong profiles is well simulated, which suggests that river avulsion is not the cause of observed convex river-long profiles. Moreover, we can identify permanent channelized flows inside valleys indicating that we do simulate river processes and not other gravitational processes such as debris flows or mass wasting. The absence of any pre-existing topography or topographic roughness precludes the early development of watersheds away from the fault trace, slowing down the evolution of the model toward a global dynamic equilibrium. However, this initial condition does not preclude the preservation of convex river-long profiles in areas where dynamic equilibrium is reached. Therefore, we conclude that regressive erosion can only partly explain the convex shape of river-long profiles away from the equilibrium area.

- Erosionnal processes and in particular the capacity of rivers to transport sediments can modify their longitudinal profile (e.g., Whipple and Tucker, 2002). We have shown that local river erosionnal rates are driven by a classical stream power law. Unfortunately, it is not possible to distinguish which erosion law model is best approached, i.e. detachment limited, transport limited, or hybrid model including transport capacity of rivers (e.g., Howard et al., 1994; Kooi and Beaumont, 1996; Whipple and Tucker, 2002; Loget et al., 2006; Cowie et al., 2008). However, we suggest that the hybrid model is the better approximation of erosion law in our experiments. Yet, investigating the role of erosionnal processes on the convex shape of 
river-long profiles requires accurate specific experiments that are currently difficult to achieve.

- Sedimentation in the hanging-wall and at the base of the fault scarp plays a major role. Indeed, sedimentation partly compensates the base level fall induced by the subsidence of the hanging-wall, which decreases the fluvial incision in the footwall. Several studies have shown that piedmont sedimentation controls partly the relief evolution in the uplifted domain (e.g., Babault et al., 2005; Carretier et al., 2005), and particularly the elevation of the topography (e.g., Babault et al., 2005).

Based on these observations, we suggest that convex river-long profiles observed in our experiments are formed initially by regressive fluvial erosion. Numerical models suggest that piedmont sedimentation coupled with a stochasticity of the rainfall can allow a long-term preservation of convex river-long profiles in the uplifted domain (Carretier et al., 2005). Our results also suggest that preservation of long-term convex river-long profiles in the footwall domain is favoured by piedmont sedimentation, but we do not have a physical explanation for the moment.

\subsection{Faceted spurs morphology}

In nature, the typical height of faceted spurs varies between $200 \mathrm{~m}$ and $1000 \mathrm{~m}$ (up to $\sim 1500 \mathrm{~m}$ for first-order generation of faceted spurs) and their mean slope ranges between $15^{\circ}$ and $35^{\circ}$ (e.g., Depolo and Anderson, 2000; Zuchiewicz and McCalpin, 2000; Mahéo et al., 2007; Petit et al., 2009a, 2009b). In our experiments, mean facet height varies between 10 and $28 \mathrm{~mm}$, which considering the model to nature spatial ratio $(1 \mathrm{~cm}=500 \mathrm{~m}$; see 2.3$)$ would be equivalent to $500 \mathrm{~m}$ to $1400 \mathrm{~m}$ in nature, respectively. This indicates a good analogy between model and nature. Modelled mean slopes range between $15^{\circ}$ and $23^{\circ}$, which corresponds well to field values except for steepest slopes which appear limited by a threshold (around $23^{\circ}$ ) 
lower than in nature (e.g., $35^{\circ}$ in the North Baikal Rift System, Petit et al., 2009b). For the slowest and the intermediate experiments, the morphometry of faceted spurs depends on the throw rate as suggested by Petit et al. (2009a,b). For the fastest experiment, heights and slopes are lower than expected due to the enhanced erosion of the escarpment in relation with experimental conditions. This experiment represents an end-member case where the fast fault slip rate may give high slopes on the escarpment, but these high slopes are rapidly destabilized by mass wasting. The reason of this destabilization probably stems from the empty space created in the hanging-wall basin, which is quickly filled by mass wasting of the escarpment, rather than by the products of river incision. This behaviour is enhanced by the lack of topographic roughness at the beginning of the experiments, which delays river network development and produces drainage basins shorter than for the two others experiments for a given fault displacement. In nature, the topographic profile of the facets is often convex even if concave ones can also be observed (e.g., Mariolakos et al., 2010). Facet profile may depend on the lithology (e.g., Mariolakos et al., 2010) and on the nature of hillslope processes that shape their surface. Indeed, under appropriate climatic (i.e., alternation of glacial and interglacial cycles in periglacial environments) and lithological (i.e., porosity higher than $10 \%$ ) conditions, it has been shown that solifluction processes favours the development of concave hillslope topographic profiles (e.g., Font et al., 2002). In our experiments, the rainfall is constant and mass wasting seems to be the main hillslope process that explains the concavity of the facet profiles. The resemblance between facet profiles in the experiments and in nature could be improved by inducing very short precipitation events instead of a continuous rainfall. Indeed, the manner in which the analogue material is eroded is very sensitive to pluviometry variations like alternation of short wet and dry periods that favour fluvial incision and decrease relatively the intensity of hillslope processes. In this case, we may alternate periods of intense erosion (with mass wasting on hillslopes and large flows 
of rivers) and weak erosion (with more diffusive hillslope processes and more entrenched rivers).

\subsection{Analogies and limitations of the modelling}

The spatial scaling has been evaluated by comparing the mechanical and physical properties (internal friction, cohesion, density) of the analogue material and of natural rocks (see section 2.3). Based on these parameters and the scaling theory, we determined that $1 \mathrm{~cm}$ in the model is equivalent to about $500 \mathrm{~m}$ in nature. However, because natural rocks exhibit a wide range of strength parameters, the uncertainty on length scaling is most probably as large as $50 \%$ (i.e., $1 \mathrm{~cm}=250 \mathrm{~m}$ to $750 \mathrm{~m}$ ). Nevertheless, this scaling value seems validated regarding the sizes and geometries of the morphologic features (e.g., faceted spurs, drainage basins, alluvial fans) that develop during model relief evolution. The time scaling $(1 \mathrm{~s}=200$ yr) has been estimated by comparing mean erosion rates measured in our experiments and in nature for normal fault footwalls (see section 2.3). Although this method is based on a crude comparison, we believe that this is a reasonable approach regarding the difficulty to dynamically scale down analogue models aimed at simulating erosion-transport processes. Presently, a rigorous time scaling is not achievable mainly because some hydraulic processes, like the river flow, cannot be scale-down properly using water and also because some hillslope processes, like the landslides occur too rapidly in nature to be correctly time scaled in models. Again, the evaluated time scaling should be considered as a first order estimation with an uncertainty that we estimate as large as about $75 \%$ (i.e., $1 \mathrm{~s}=50$ to $350 \mathrm{yr}$ ). This temporal scale makes the analogue modelling suited to the study of relief dynamics at the scale of a few thousand years and during a period of a few millions years. By contrast, the analysis of individual river evolution is out of reach because in nature rivers evolve at a much shorter time scale (typically a few tens of years which correspond to a few hundred of 
milliseconds in the experiments) than that attainable in the analogue modelling. Consequently, the flat-floored channels observable in the experiments should be considered as equivalent to main flood plains of braided rivers in nature and not as individual rivers.

The initial $1^{\circ}$ tilted planar surface facilitated performing series of experiments sharing the same initial conditions but has some impact on the development of the river network. The low dipping flat surface erode slowly because channelling process is limited by the lack of topographic roughness and because the $1^{\circ}$ slope is below the threshold slope from which particles are detached by the water flow. In nature, river networks and watersheds often preexist before fault inception favouring a rapid erosionnal response to ongoing uplift. The analogue physical properties, in particular its thixotropic behaviour, make difficult the simulation of a pre-existing drainage network or topographic roughness. New technical developments to solve this problem are being tested. Using a constant rainfall during the whole experiment is only compatible with wet natural climatic conditions. The experimental results should not be compared, then, to morphologies developing under arid climatic conditions or submitted to climatic fluctuations associated to glaciation cycles. These limitations probably explain why the triangular facets of the experiments do not display a typical convex shape as often observed in nature, but a concave one. In preliminary tests with twice less rainfall, we observed the development of a fault escarpment with a high slope (70$80^{\circ}$ ). Therefore, the erodibility behaviour of the analogue material would be probably improved by changing the manner in which the rainfall is sprayed (see also section 4.3).

In our analogue experiments, erosion processes include river incision, hillslope diffusion, mass wasting and landsliding depending on local rainfall/morphologic/tectonic conditions. These processes are dynamically very similar to those that shape natural landscapes but their relative efficiency can be slightly different. Indeed, analogue material cohesion and permeability are two key parameters that determine the river incision capacity 
and the hillslope processes intensity (i.e., Graveleau et al., accepted). So varying these parameters has a strong effect on the model morphology. If the cohesion is too high and the permeability too low $\left(\mathrm{Co}>2000 \mathrm{~Pa}\right.$ and $\left.\mathrm{k}<10^{-13} \mathrm{~m}^{2}\right)$, bad-land type morphologies develop. On the opposite, if the cohesion is too low and the permeability too high $(\mathrm{Co}<100 \mathrm{~Pa}$ and $\mathrm{k}>$ $10^{-12} \mathrm{~m}^{2}$ ), model reliefs are smoothed by intense hillslope processes including landsliding and mass wasting (Graveleau et al., accepted). Based on the modelled morphologies we can conclude that the cohesion $(\mathrm{Co}=500-700 \mathrm{~Pa})$ and permeability $\left(\mathrm{k}=5.10^{-12} \mathrm{~m}^{2}\right)$ of our analogue material are satisfactory. They could still be modified to increase the capacity of river incision, hence decrease relatively the intensity of the hillslope processes. Although out of reach of this first experimental study under a single and constant rainfall, such modifications may favour the preservation of convex faceted spur surfaces and accelerate the development of the drainage network. The erodibility behaviour of the analogue material is sensitive to a balance between the rainfall simulation and the analogue material properties (cohesion, permeability) but testing this sensibility is far beyond the scope of this paper.

\section{Conclusion}

We performed analogue experiments aimed at studying the morphologic evolution of a mountain range bounded by a normal fault. We tested the role of the fault slip rate on different morphologic and morphometric markers by performing three experiments with different fault slip rates under a given uniform rainfall rate.

- Our results indicate a strong coupling between the throw rate and erosion rates (headward erosion, incision and hillslope erosion rates). The ratio between the incision rate and the throw rate is $0.42+/-0.4$ at the fault scarp. The ratio between the headward erosion rate and the throw rate is $4.00+/-0.25$. 
- We cannot evidence, for this experimental setup, any clear relationship between the throw rate and facet morphology.

- The analysis of faceted spurs morphometries shows a good analogy with nature even if their surfaces are too carved by mass wasting processes.

- Our models do not exhibit a global steady-state, but a local equilibrium is reached in rivers up to $10 \mathrm{~cm}$ upfault, allowing us to examine the stream-power law in this area.

- The averaged erosion rate can be explained by a stream power law of rivers with $\mathrm{m}$ and $\mathrm{n}$ exponents equal to 1 and $K$ is correlated to the fault slip rate.

- The preservation of convex experimental river-long profiles in this area suggests that such a shape could exist in landscapes under a constant throw rate and during long time periods (may be up to steady state conditions).

\section{Acknowledgments:}

This study would have been impossible without financial assistance from INSUCNRS and from Université Pierre et Marie Curie (UPMC). VS received a Ministry of Research and Education PhD scholarship granted by UPMC. We are indebted to C. Romano for building the experimental set-up and for technical assistance. We thank F. Graveleau for fruitful discussions and acknowledge both the thorough reading and the constructive comments of two anonymous reviewers. 


\section{REFERENCES}

Arjannikova A., Larroque C., Ritz J.-F., Déverchère J., Stéphan J.-F., Arjannikoy S., San'kov V., 2004. Geometry and kinematics of recent deformation in the Mondy-Tunka area (southwesternmost Baikal rift zone, Mongolia-Siberia), Terra Nova, 16, 265-272.

Armijo, R., Tapponnier, P., Mercier, J.L., Tong-Lin, H., 1986. Quaternary extension in southern tibet: field observations and tectonic implications, Journal of Geophysical Research, 91(B14), 13803-13872, doi:10.1029/JB091iB14p13803.

Armijo, R., Lyon-caen, H., Papanastassiou, D., 1991. A possible normal-fault rupture for the 464-Bc Sparta Earthquake, Nature, v. 351(6322), 137-139.

Armijo, R., Meyer, B., King, C.P., Rigo, A., Papanastassiou, D., 1996. Quaternary evolution of the Corinth Rift and its implications for the Late Cenozoic evolution of the Aegean, Geophys. J. Int., 126(1), 11-53.

Avouac, J.-P., Burov, E.B., 1996. Erosion as a driving mechanism of intracontinental mountain growth, Journal of Geophysical Research, 101(B8), 17747-17769, doi:10.1029/96JB01344.

Avouac J.-P., 2003. Mountain Building, Erosion, and the Seismic Cycle in the Nepal Himalaya, Adv. Geophys., 46, 1-80.

Babault, J., Bonnet, S., Crave, A., Van Den Driessche, J., 2005. Influence of piedmont sedimentation on erosion dynamics of an uplifting landscape: An experimental approach, Geology, 33, 301-304, doi: 10.1130/G21095.1.

Beaumont, C.P., Fullsack, P., Hamilton, J., 1992. Erosional control of active compressional orogens, in Thrust Tectonics, edited by K.R. McClay, pp. 1-18, Chapman and Hall, New York.

Birot, P., 1958. Morphologie Structurale, tome second, types d'évolution du relief, théories orogéniques. Presses Universitaires de France, 464 pp. 
Bonnet, S., Crave, A., 2003. Landscape response to climate change: insights from experimental modeling and implications for tectonic versus climatic uplift of topography. Geology, 31(2) : 123-136.

Bonnet, S., Crave, A., 2006. Macroscale dynamics of experimental landscapes, Geological Society, London, Special Publications, January 1, 253(1): 327-339.

Bonnet, S., 2009. Shrinking and splitting of drainage basins in orogenic landscapes from the migration of the main drainage divide, Nature Geoscience, 2, 766-771, doi:10.1038/NGEO666.

Burbank, D.W., Anderson, R.S., 2001. Tectonic Geomorphology, Blackwell Science.

Burchfiel, B.C., Brown, E.T., Qidong, D., Xianyue, F., Jun, L., Molnar, P., Jianbang, S., Zhangming, W., Huichuan, Y., 1999. Crustal shortening on the margins of the Tien Shan, Xinjiang, China, Int. Geol. Rev., 41, 665-700.

Byerlee, J., 1978. Friction of rock. Pure applied Geophysics, 116, 615-626.

Carozza, J.M., Baize, S., 2004. L'escarpement de faille de la Têt est-il le résultat de la tectonique active Plio-Pléistocène ou d'une exhumation Pléistocène ? Comptes Rendus Geosciences, 336, 3, 217 - 226. doi:10.1016/j.crte.2003.10.026.

Carretier, S., Lucazeau, F., 2005. How does alluvial sedimentation at range fronts modify the erosional dynamics of mountain catchments? Basin research, 17, 361-381, doi: 10.1111/j.1365-2117.2005.00270.x.

Cobbold, P.R., Jackson, M.P.A., 1992. Gum rosin (colophony): a suitable material for thermomechanical modelling of the lithosphere, Tectonophysics, 210, 255-271.

Cotton, C.A., 1950. Tectonic scarps and fault valleys, Geol. Soc. Am. Bull., 61, 717 - 758. doi:10.1130/0016-7606(1950)61[717:TSAFV]2.0. CO;2. 
Cowie, P.A., Attal, M., Tucker, G.E., Whittaker, A.C., Naylor, M., Ganas, A., Roberts, G. P., 2006. Investigating the surface process response to fault interaction and linkage using a numerical modelling approach, Basin Res., 18, 231-266.

Cowie, P.A., Whittaker, A.C., Attal, M., Roberts, G. P., Tucker, G.E., Ganas, A., 2008. New constraints on sediment-flux-dependent river incision: Implications for extracting tectonic signals from river profiles, Geology, 36, 535-538, doi:10.1130/G24681A.1.

Davis, W.M., 1903. The mountain ranges of the Great Basin : Harvard Univ. Mus. Comp. Zoology Bull., Geol. Ser., 40, 3, 129 - 177.

Davy, P., Cobbold, P.R., 1991. Experiments on shortening of a 4-layer model of the continental lithosphere, Tectonophysics, 188, 1-25.

Densmore, A.L., Ellis, M.A., Anderson, R.S., 1998. Landsliding and the evolution of normalfault-bounded mountains, Journal of Geophysical Research, 103, B7, 15203-15219.

Densmore, A.L., Dawers, N.H., Gupta, S., Guidon, R., Goldin, T., 2004. Footwall topographic development during continental extension, Journal of Geophysical Research, 109, F03001, doi:10.1029/2003JF000115.

Densmore, A.L., Hetzel, R., Ivy-Ochs, S., Krugh, W.C., Dawers, N., Kubik, P., 2009. Spatial variations in catchment-averaged denudation rates from normal fault footwalls, Geology, 37, 1139-1142, doi: 10.1130/G30164A.1.

DePolo, C.M., Anderson, J.G., 2000. Estimating the slip rates of normal faults in the Great Basin, USA, Basin Res. , 12, 227-240. doi:10.1046/j.1365-2117.2000.00131.x.

Ellis, G.A., Densmore, A.L., Anderson, R.S., 1999. Development of mountainous topography in the Basin Ranges, USA, Basin Research, 11, 21-41.

Font, M., Lagarde, J.L., Amorese, D., Coutard, J.P., Ozouf, J.C., 2002. Une méthode de quantification de la dégradation d'un escarpement de faille au cours des cycles climatiques du 
Quaternaire : la faille de Jobourg (Nord Cotentin, France), Comptes Rendus Geosciences, $334,171-178$.

Ganas, A., Pavlides, S., Karastathis, V., 2005. DEM-based morphometry of range-front escarpments in Attica, central Greece, and its relation to fault slip rates, Geomorphology, 65, 301-319, doi:10.1016/j.geomorph.2004.09.006.

Graveleau, F., Dominguez, S., 2008. Analogue modelling of the interaction between tectonics, erosion and sedimentation in foreland thrust belts. Comptes Rendus Geosciences, 340, 5, $324-333$, doi:10.1016/j.crte.2008.01.005.

Graveleau, F., Hurtrez, J.-E., Dominguez, S., Malavieille, J., accepted. A new experimental material for modelling relief dynamics and interactions between tectonics and surfaces processes. Tectonophysics.

Hack, J.T., 1957. Studies of longitudinal stream profiles in Virginia and Maryland, U.S. Geological Survey, Professional Paper, 294(B), 45-97.

Hack, J.T., 1960. Interpretation of erosional topography in humid temperate regions, American Journal of Science, 258, 80-97.

Hamblin, W.K., 1976. Patterns of displacement along the Wasatch Fault, Geology, 4, 619 622, doi:10.1130/0091-7613(1976)4<619: PODATW>2.0.CO;2.

Harkins, N., Kirby, E., Heimsath, A., Robinson, R., Reiser, U., 2007. Transient fluvial incision in the headwaters of the Yellow River, northeastern Tibet, China, Journal of Geophysical Research, 112, F03S04, doi: 10.1029/2006JF000570.

Hasbargen, L.E. and Paola, C., 2000. Landscape instability in an experimental drainage basin, Geology, 28, 1067-1070.

Horsfield, W.T., 1977. An experimental approach to basement-controlled faulting. In: R.T.C. Frost \& A.J. Dikkers (eds.): Fault tectonics in N.W. Europe. Geol. Mijnbouw, 56, 363-370. 
Howard, A.D., Dietrich, W.E., Seidl, M.A., 1994. Modeling fluvial erosion on regional to continental scales, Journal of Geophysical Research, 99, B7, 13971-13986.

Hubbert M.K., 1937. Theory of scale models as applied to the study of geologic structures, Bulletin of the Geological Society of America, 48, 1459-1520.

Hubbert M.K., 1951. Mechanical basis for certain familiar geologic structures, Bulletin of the Geological Society of America, 62, 355-372.

Hubert-Ferrari, A., Suppe, J., Gonzalez-Mieres, R., Wang, X., 2007. Mechanisms of active folding of the landscape (southern Tian Shan, China), J. Geophys. Res., v. 112(B3), doi : 10.1029/2006JB004362.

Hurtrez, J.-E., Sol, C., Lucazeau, F., 1999. Effect of drainage area on hypsometry from an analysis of small-scale drainage basins in the Siwalik hills (central Nepal), Earth Surf. Process. Landforms, 24, $799-808$.

King, G.C.P., Stein, R.S., Rundle, J.B., 1988. The growth of geological structures by repeated earthquakes 1. Conceptual Framework, Journal of Geophysical Research, 93, B11, 13307 13318.

Kooi, H., Beaumont, C., 1996. Large-scale geomorphology: Classical concepts reconciled and integrated with contemporary ideas via a surface processes model, Journal of Geophysical Research, 101, B2, 3361-3386.

Krantz, R., 1991. Measurements of friction coefficients and cohesion for faulting and fault reactivation in laboratory models using sand and sand mixtures, Tectonophysics, 188, 1-2, 203-207.

Lagabrielle, Y., Chauvet, A., 2008. The role of extensional tectonics in shaping Cenozoic New-Caledonia, Bull. Soc. Géol. Fr., 179, 3, 197-202. 
Lague, D., Crave, A., Davy, P., 2003. Laboratory experiments simulating the geomorphic response to tectonic uplift, Journal of Geophysical Research, 108(B1), 2008, doi:10.1029/2002JB001785.

Lama, R.D., Vutukuri, V.S., 1978. "Handbook on Mechanical Properties of Rocks" Testing Techniques and Results - Vol. III, No. 2, Trans Tech Publications, (International Standard Book Number 0-87849-022-1, Clausthal, Germany).

Larroque C., Ritz J.-F., Stéphan J.-F., San'kov V., Arjannikova A., Calais E., Déverchère J., Loncke L., 2001. Interaction compression-extension à la limite Mongolie-Sibérie : analyse préliminaire des déformations récentes et actuelles dans le bassin de Tunka. Comptes Rendus Geosciences, 332, 177-184.

Loget N., Davy P., and Van den Driessche J., 2006. Mesoscale fluvial erosion parameters deduced from the modeling of the Mediterranean sea-level drop during the Messinian (Late Miocene). Journal of Geophysical Research, 111, F03005, doi:10.1029/2005JF000387.

Mahéo G., Leloup, P.H., Valli, F., Lacassin, R., Arnaud, N., Paquette, J.-L., Fernandez, A., Haibing, L., Farley, K.A., Tapponnier, P., 2007. Post 4 Ma initiation of normal faulting in southern Tibet. Constraints from the Kung Co half graben. Earth and Planetary Science Letters, 256, 233 - 243, doi:10.1016/j.eps1.2007.01.029.

Malverti, L., Lajeunesse, E., Métivier, F., 2008. Small is beautifull: Upscaling from microscale laminar to natural turbulent rivers, Journal of Geophysical Research, 113, F04004, doi:10.1029/2007JF000974.

Mariolakos, I., Nikolopoulos, V., Bantekas, I., Palyvos, N., 2010. Oracles on faults: a probable location of a "lost" oracle of Apollo near Oraviai (Northern Evia Island, Greece) viewed in its geological and geomorphological context, Bull. Geol. Soc. Of Greece, XLIII (2), 829-844. 
McCalpin J.P., Khromovskikh V.S., 1995. Holocene paleosismicity of the Tunka fault, Baikal rift, Russia, Tectonics, 14, 3, 594-605.

Merritts, D.J., Vincent, K.R., Wohl, E.E., 1994. Long river profiles, tectonism, and eustasy: A guide to interpreting fluvial terraces, Journal of Geophysical Research, 99, B7, 1403114050.

Meyer, B., Armijo, R., Dimitrov, D., 2002. Active faulting in SW Bulgaria: possible surface rupture of the 1904 Struma earthquakes, Geophys. J. Int., 148, 246-255.

Montgomery, D.R., Dietrich, W.E., 1992. Channel initiation and the problem of landscape scale, Science, 255, 826-830.

Montgomery, D.R., 2001. Slope distributions, threshold hillslopes, and steady-state topography, American Journal of Science, 301, 432-454.

Montgomery, D.R., Balco, G., Willett, S.D., 2001. Climate, tectonics and the morphology of the Andes, Geology, 29, 579-582.

Niemann, J.D. and Hasbargen, L.E., 2005. A comparison of experimental and natural drainage basin morphology across a range of scales, Journal of Geophysical Research, 110, F04017, doi:10.1029/2004JF000204.

Paola P., Straub K., Mohrig, D, Reinhardt, L., 2009. The "unreasonable effectiveness" of stratigraphic and geomorphic experiments, Earth-Science Reviews 97, 1-43. doi:10.1016/j.earscirev.2009.05.003.

Pelletier, J.D., 2003. Drainage basin evolution in the Rainfall Erosion Facility : dependence on initial conditions, Geomorphology, $53: 183-196$.

Pelletier, J.D., DeCelles, P.G., Zandt. G., 2010. Relationships among climate, erosion, topography, and delamination in the Andes: A numerical modeling investigation, Geology, 38(3): $259-262$. 
Petit, C., Gunnell, Y., Gonga-Saholiariliva, N., Meyer, B., Séguinot, J., 2009a. Faceted spurs at normal fault scarps: Insights from numerical modeling, Journal of Geophysical Research, 114, B05403, doi:10.1029/2008JB005955.

Petit, C., Meyer, B., Gunnell, Y., Jolivet, M., San'kov, V., Strak, V., Gonga-Saholiariliva, N., 2009b. Height of faceted spurs, a proxy for determining long-term throw rates on normal faults: Evidence from the North Baikal Rift System, Siberia, Tectonics, 28, TC6010, doi:10.1029/2009TC002555.

Richard, P., 1991. Experiments on faulting in a two-layer cover sequence overlying a reactivated basement fault with oblique-slip, Journal Of Structural Geology, 13, 4, 459-469.

Roe, G.H., Stolar, D.B., Willett, S.D, 2006. Response of a steady-state critical wedge orogen to changes in climate and tectonic forcing, Geological Society of America Special Papers, $398(0), 227-239$.

San'kov, V., Déverchère, J., Gaudemer, Y., Houdry, F., Filippov, A., 2000. Geometry and rate of faulting in the North Baikal Rift, Siberia, Tectonics, 19, 4, 707-722.

Shemenda, A.I, 1983. Similarity criteria for mechanical modeling of the tectonic processes, Geol. geofiz., 24, 10, 8-16.

Sklar, L.S., Dietrich, W.E., 1998. River longitudinal profiles and bedrock incision models: Stream power and the influence of sediment supply. In River over rock : Fluvial processes in bedrock channels, edited by K.J.a.W Tinkler, E.E. ; AGU Monograph, 237 - 260.

Snyder, N.P., Whipple, K.X, Tucker, G.E., Merritts, D.J., 2000. Lanscape response to tectonic forcing: Digital elevation model analysis of stream profiles in the Mendocino triple junction region, northern California, GSA Bulletin, 112, 8, 1250-1263.

Stein, R.S., King, G.C.P., Rundle, J.B., 1988. The growth of geological structures by repeated earthquakes 2. Field examples of continental dip-slip faults, Journal of Geophysical Research, 93, B11, 13319-13331. 
Stock, J.D., Montgomery, D.R., 1999. Geologic constraints on river bedrock incision using the stream power law, Journal of Geophysical Research, 104, B3, 4983-4993.

Stock et al., 2009. Spatial and temporal variations in denudation of the Wasatch Mountains, Utah, USA, Lithosphere, 1, 1, 34-40, doi: 10.1130/L15.1.

Strahler, A.N., 1952. Hypsometric (area-altitude) analysis of erosional topography, Geological Society of America Bulletin, 63, 1117 - 1142.

Tucker, G.E., McCoy, S.W., Whittaker, A.C., Roberts, G.P., Lancaster, S.T., Phillips, R., 2011. Geomorphic significance of postglacial bedrock scarps on normal-fault footwalls, Journal of Geophysical Research, 116, F01022, doi:10.1029/2010JF001861.

Valla, P.G., Van Der Beek, P.A., Carcaillet, J., 2010. Dating bedrock gorge incision in the French Western Alps (Ecrins-Pelvoux massif) using cosmogenic ${ }^{10} \mathrm{Be}$, Terra Nova, 22, 18-25, doi: 10.1111/j.1365-3121.2009.00911.x.

Wallace, R.E., 1978. Geometry and rates of change of fault-related fronts, north-central Nevada, J. Res. U. S. Geol. Surv., 6, 637-650.

Whipple, K.X., Tucker, G.E, 1999. Dynamics of the stream-power river incision model: Implications for height limits of mountain ranges, landscape response timescales, and research needs, Journal of Geophysical Research, 104, B8, 17661-17674.

Whipple, K.X., 2001. Fluvial landscape response time: How plausible is steady-state denudation? American Journal of Science, 301, 313-325.

Whipple, K.X., Tucker, G.E, 2002. Implications of sediment-flux-dependent river incision models for landscape evolution, Journal of Geophysical Research, 107, B2, doi: 10.1029/2000JB000044.

Whittaker, A.C., Attal, M., Cowie, P.A., Tucker, G.E., Roberts, G., 2008. Decoding temporal and spatial patterns of fault uplift using transient river long profiles, Geomorphology, 100, 506-526. 
Willett, S.D., 1999. Orogeny and orography: The effects of erosion on the structure of mountain belts, Journal of Geophysical Research, 104, 28957-28981.

Willgoose, G., 1994. A physical explanation for an observed area-slope-elevation relationship for catchments with declining relief, Water Resources Research, 30, 2, 151-159.

Zuchiewicz, W.A., McCalpin, J.P., 2000. Geometry of faceted spurs on an active normal fault: case study of the Central Wasatch Fault, Utah, U.S.A. Annales Societatis Geologorum Poloniae, 70: 231-249. 
Table 1: Physical properties of the granular elements forming the analogue material made of a water-saturated paste of glass microbeads, silica powder and plastic powder.

Table 2: Time and fault slips for successive DEMs of three experiments achieved with fault slip rates of $3.17,6.34$ and $12.68 \mu \mathrm{m} / \mathrm{s}$. To simplify the presentation of the results in the text and in the figures, we call these experiments the $3 \mu \mathrm{m} / \mathrm{s}$, the $6 \mu \mathrm{m} / \mathrm{s}$ and the $12 \mu \mathrm{m} / \mathrm{s}$ experiment. 
Figure 1: (A) Synthetic block diagram showing typical morphologic and structural features associated with a normal fault. (B) Corresponding cross section. $\mathrm{H}_{\mathrm{f}}$ is the triangular facet height. The dashed gray line is the theoretical profile without erosion (i.e., the profile of the cumulated co-seismic and inter-seismic deformations) (C) and (D) Photographies of faceted spurs along normal faults bounding lake Baikal (Pictures by C. Petit, approximate geographical location: $51^{\circ} 57.54^{\prime} \mathrm{N} 105^{\circ} 15.50^{\prime} \mathrm{E}$ (top) and $53^{\circ} 23.30^{\prime} \mathrm{N}$ et $107^{\circ} 22.45^{\prime} \mathrm{E}$ (bottom)).

Figure 2: (A) Experimental set-up constituted by a deformation device, a rainfall system and CCD cameras coupled with a laser interferometer used to monitor model topography. (B) Schematic cross-sections of the model at initial and (C) final stages with typical faultperpendicular profiles along crests and rivers (red and blue lines, respectively).

Figure 3: (A) Picture of the final stage of the $6 \mu \mathrm{m} / \mathrm{s}$ experiment and (B) morphological interpretation. (C) Perspective view draped on the corresponding DEM with three fault perpendicular profiles running along a river (blue line), along a crest and across a facet (red line) and along a crest and a facet edge (green line).

Figure 4: Successive DEMs of the $6 \mu \mathrm{m} / \mathrm{s}$ experiment. The corresponding fault slips are indicated. The elevation is relative to the lowest point of the DEM.

Figure 5: DEMs of the final stage (i.e., corresponding to a fault slip of $\sim 9 \mathrm{~cm}$ ) for the $3 \mu \mathrm{m} / \mathrm{s}$, $6 \mu \mathrm{m} / \mathrm{s}$ and $12 \mu \mathrm{m} / \mathrm{s}$ experiments.

Figure 6: (A) Topographic profiles of the final stage of the $6 \mu \mathrm{m} / \mathrm{s}$ experiment and (B) closeup view pointing to the measured quantities (see Figure $3 \mathrm{C}$ for legend). The gray triangle upfault is the area where we could not measure eroded material (see corresponding area in Figure 14).

Figure 7: (A) Relationship between main river length L and upstream drainage area A. The data are acquired on all the drainage basins for each experiment. The solid line is the best 
fitting regression line which follows the power law described by Hack (1957). (B) Same relationship for the Tunka half-graben in the Baikal Rift System.

Figure 8: (A) Hypsometric curves for the whole footwall at several stages of the three experiments. The hypsometric curve for the Tunka mountain range is shown for comparison.

(B) Hypsometric curves for a given fault slip (45.6 mm, left and $91.3 \mathrm{~mm}$, right). (C) Hypsometric curves for a given time (7200 s, left and $14400 \mathrm{~s}$, right).

Figure 9: (A) DEM superimposed on photography of the final stage of the $6 \mu \mathrm{m} / \mathrm{s}$ experiment with (B) corresponding along river and facet profiles. (C) gray-shaded DEM of the central part of the mountain range of the Tunka half-graben with (D) representative examples of river and facet profiles.

Figure 10: Evolution of the topography along rivers for the $6 \mu \mathrm{m} / \mathrm{s}$ experiment. The referential for the elevations is (A) the top of the footwall (showing base level fall) and (B) the base level (showing the length along which rivers reach equilibrium). $\mathrm{F}$ is the position of the fault trace for the last stage (fault slip of $91.3 \mathrm{~mm}$ ).

Figure 11: Relationship between local river slope and upstream drainage area for the last stage of the three experiments.

Figure 12: (A) Facet slope and (B) facet height versus fault slip for the three experiments. The thick lines correspond to the mean values. The dashed lines correspond to the minimal or maximal values in order to give an estimate of the standard deviation.

Figure 13: Erosion rates at a given distance upfault versus fault slip for the three experiments. $(A, C)$ Finite erosion rates averaged since the beginning of the experiment $(H R / T)$ and $(B, D)$ erosion rates averaged between two successive DEMs $(\Delta \mathrm{HR} / \Delta \mathrm{t})$.

Figure 14: Averaged erosion rates along rivers and along crests (blue and green lines and symbols, respectively. See Figure 3B for an example of location of profiles) since the beginning of the experiment $(\mathrm{HR} / \mathrm{T})$ for a given fault slip of $6.85 \mathrm{~cm}$ versus distance upfault, 
for the three experiments. The gray rectangle corresponds to the area without meaningful values of eroded material (see Figure 6B).

Figure 15: Averaged erosion rates $(\mathrm{HR} / \mathrm{T})$ measured along rivers for each experiment and for the time span corresponding to the cumulated fault slip of $91.3 \mathrm{~mm}$ versus (A) upstream drainage area, (B) local river slope and (C) $A \times S$. The data presented correspond to the area where river profile is at equilibrium. (D) $K$ parameter versus the fault slip rate (equation 5). 
Fig 1

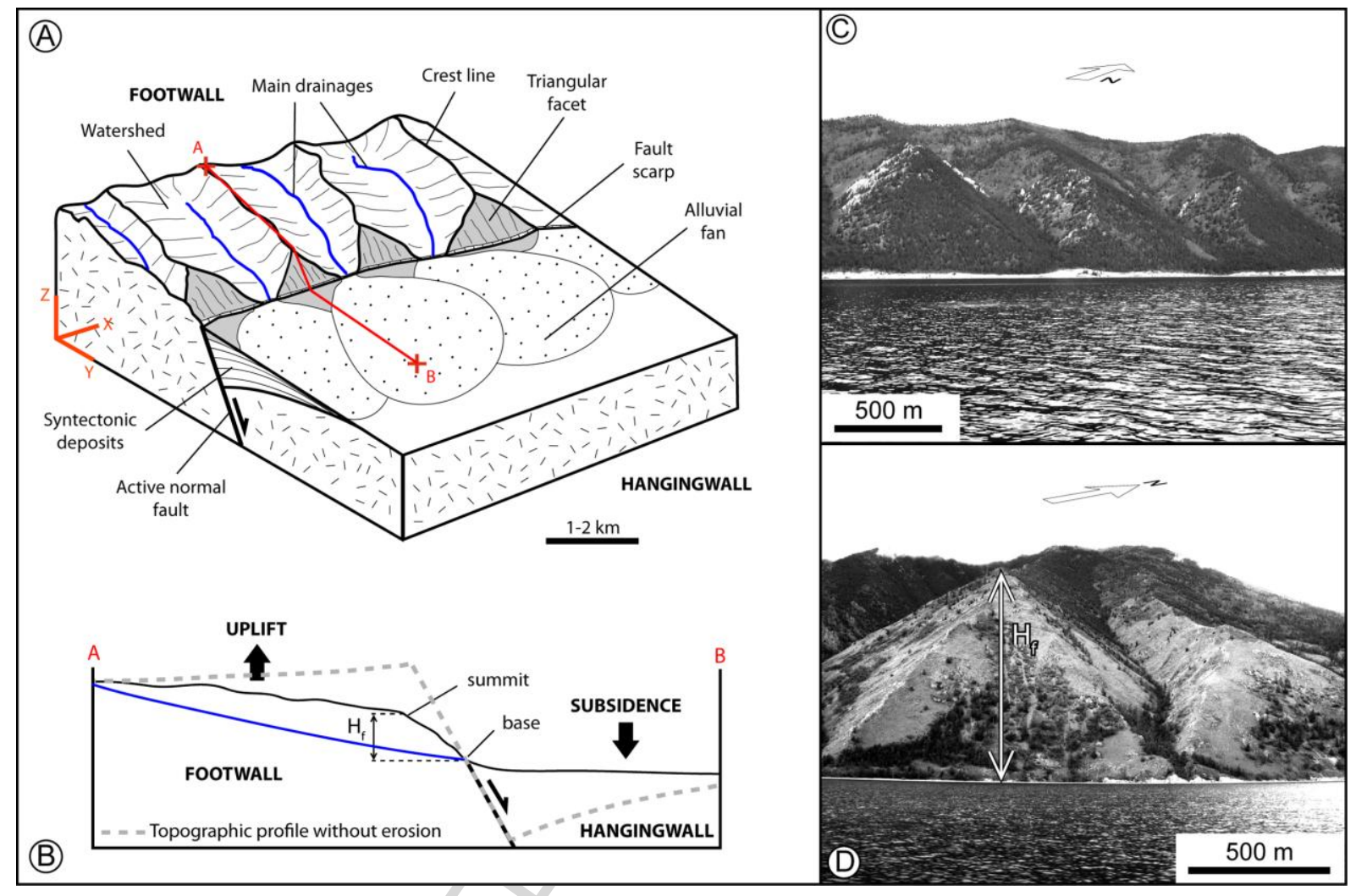


Fig 2

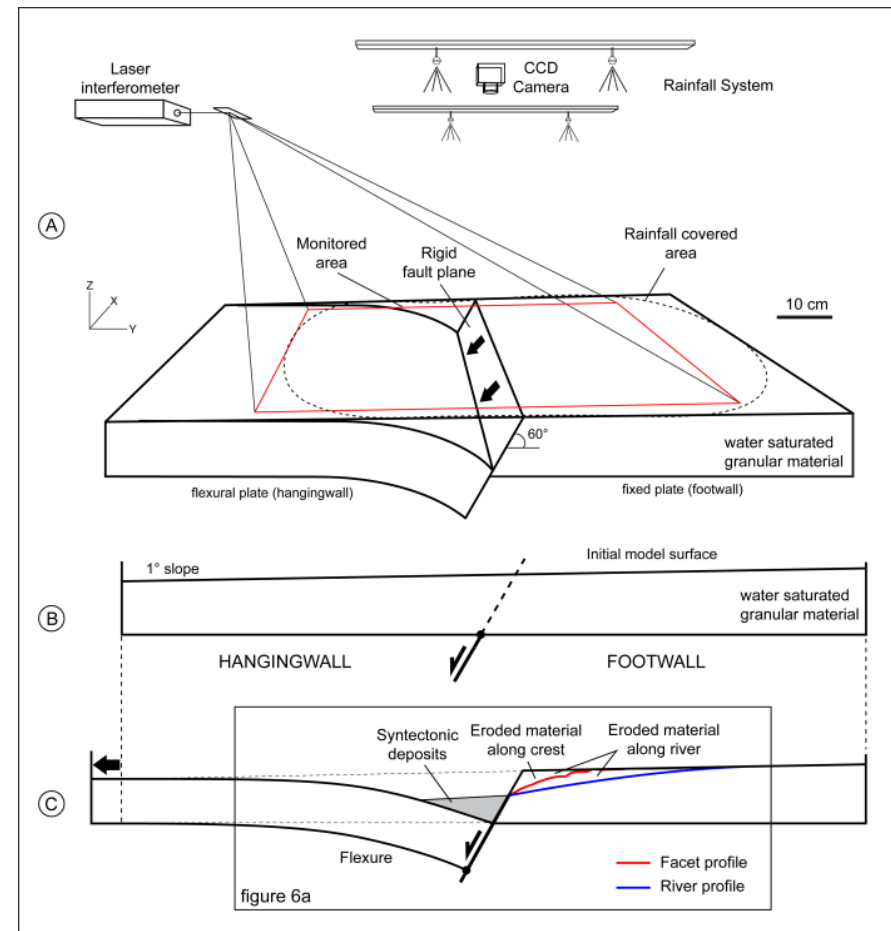


Fig 3

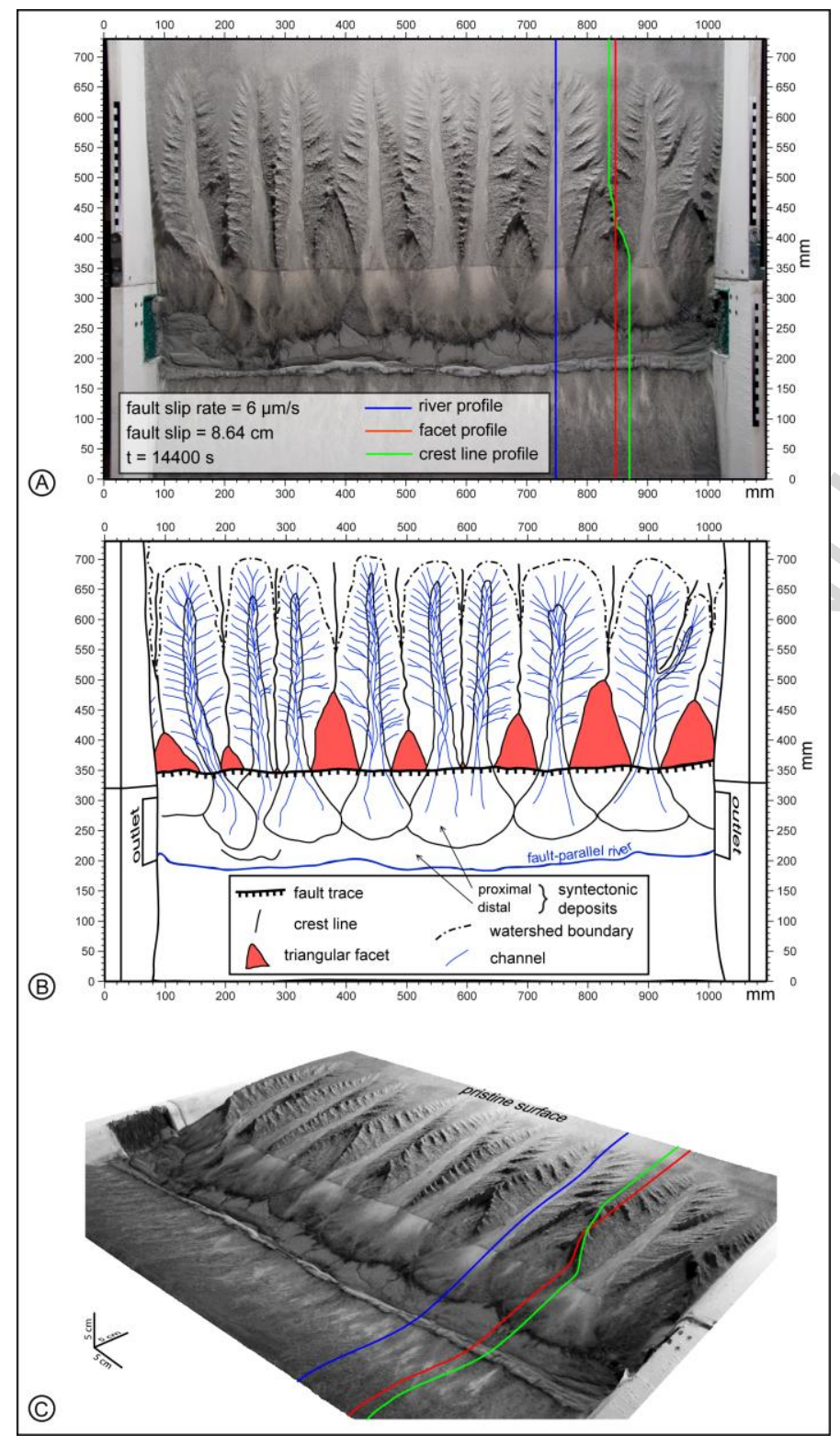


Fig 4
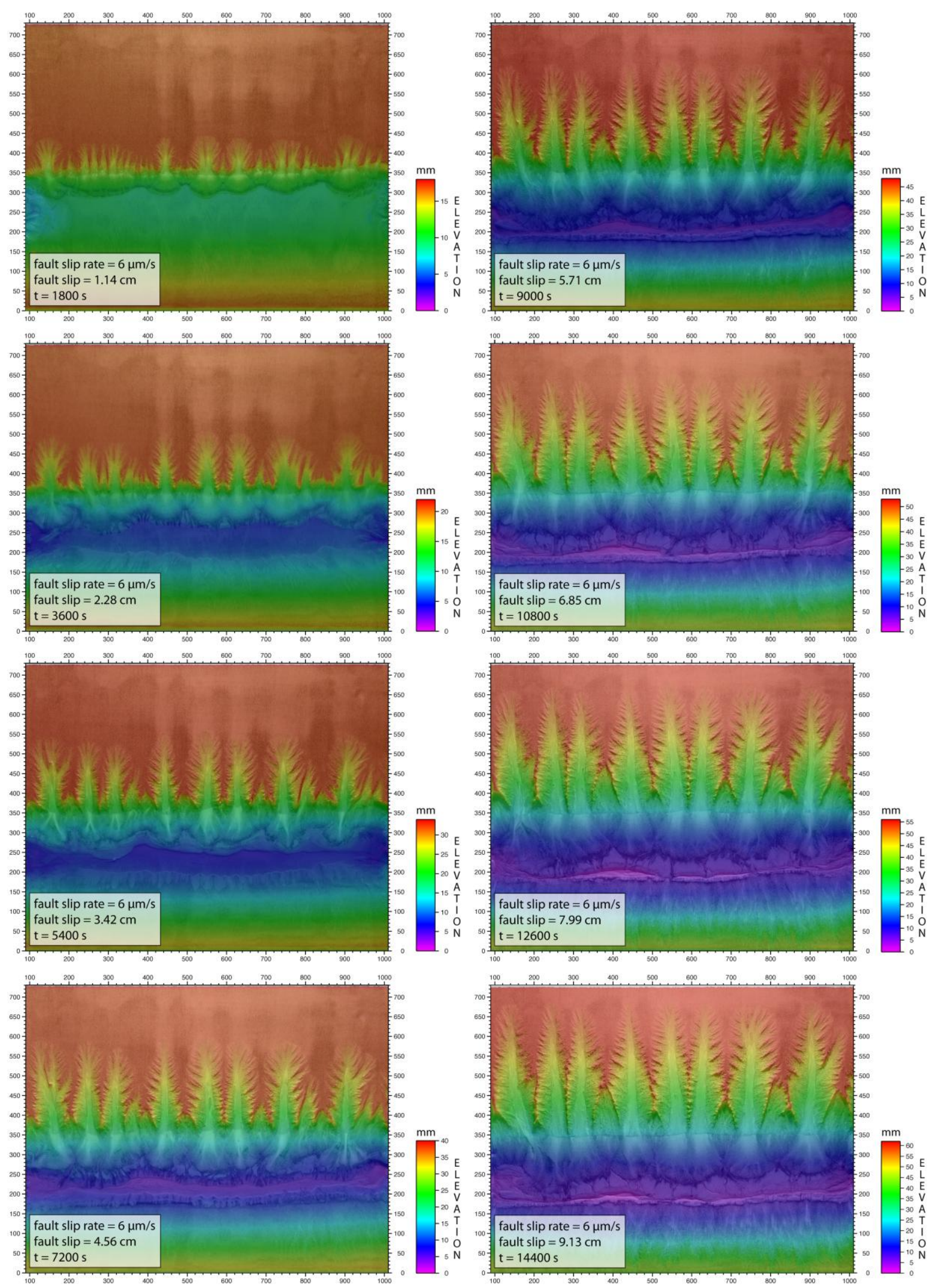
Fig 5
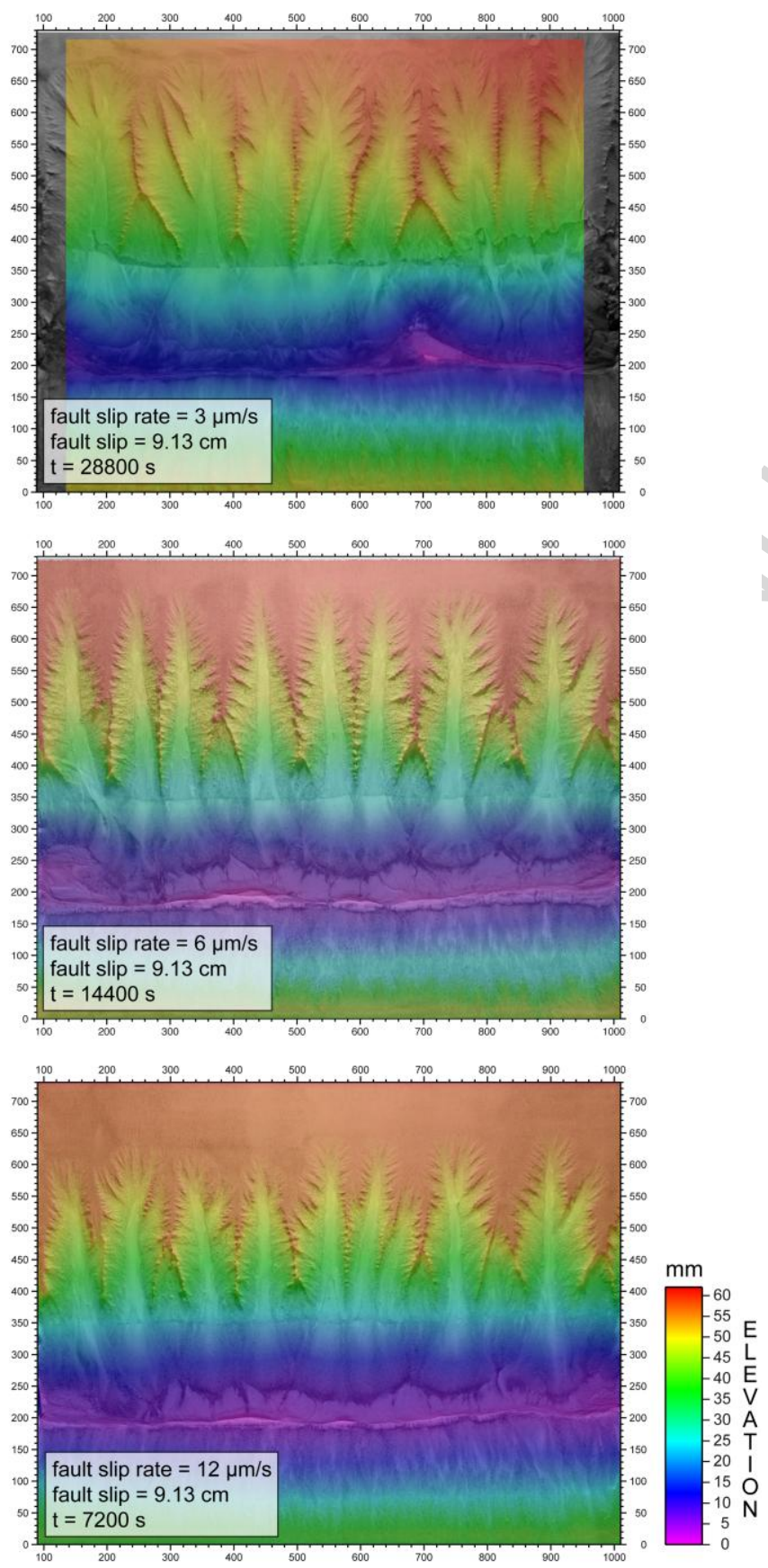
Fig 6

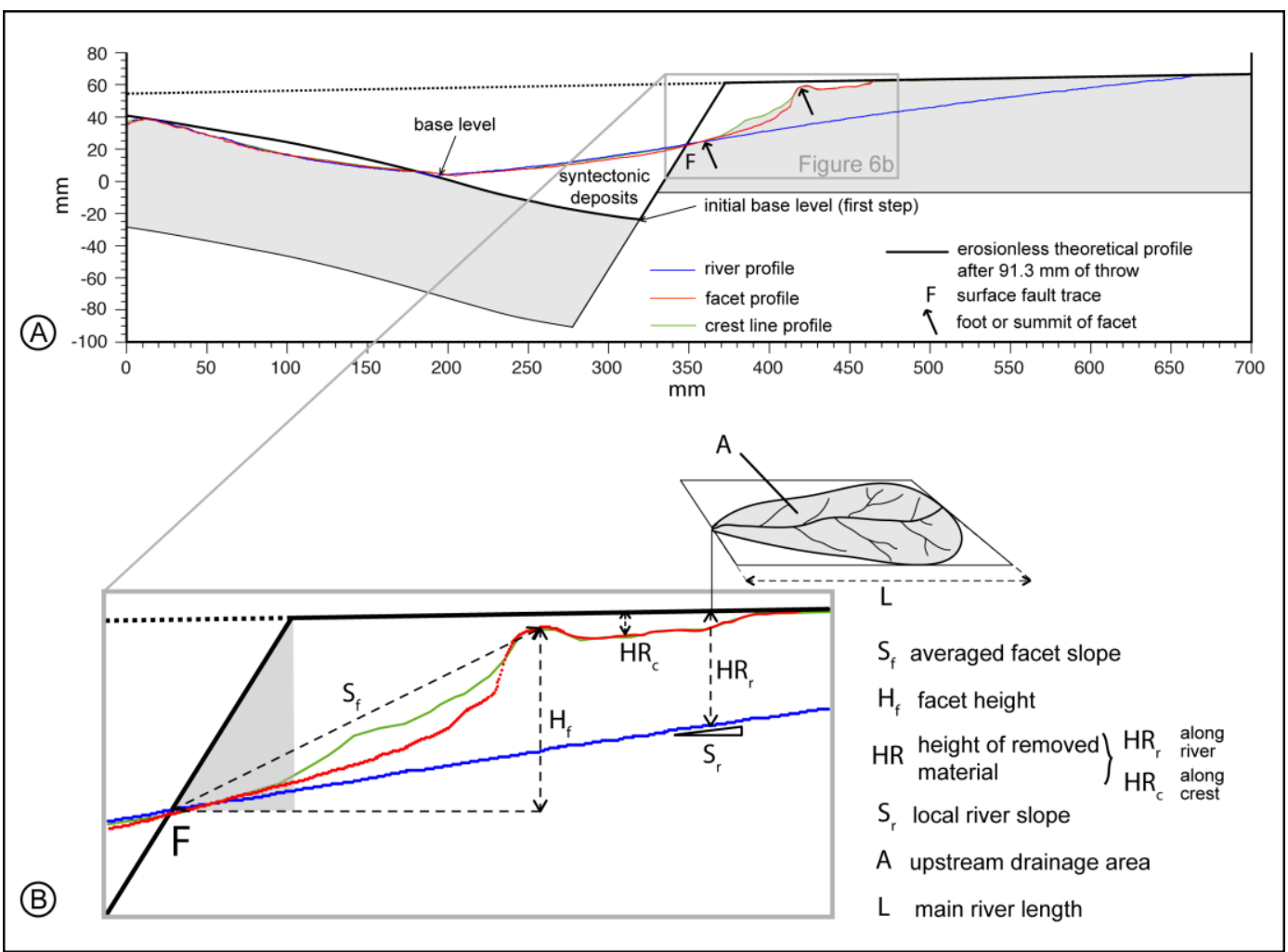


Fig 7
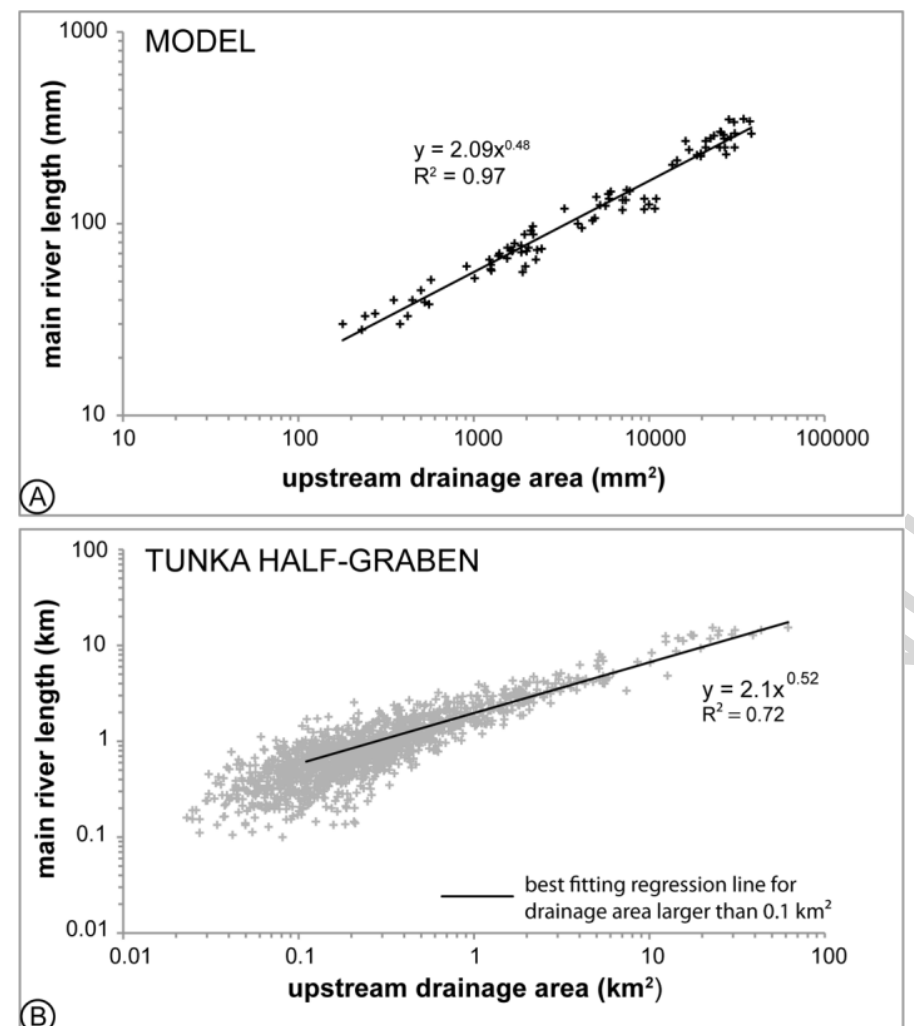

(B) 
Fig 8
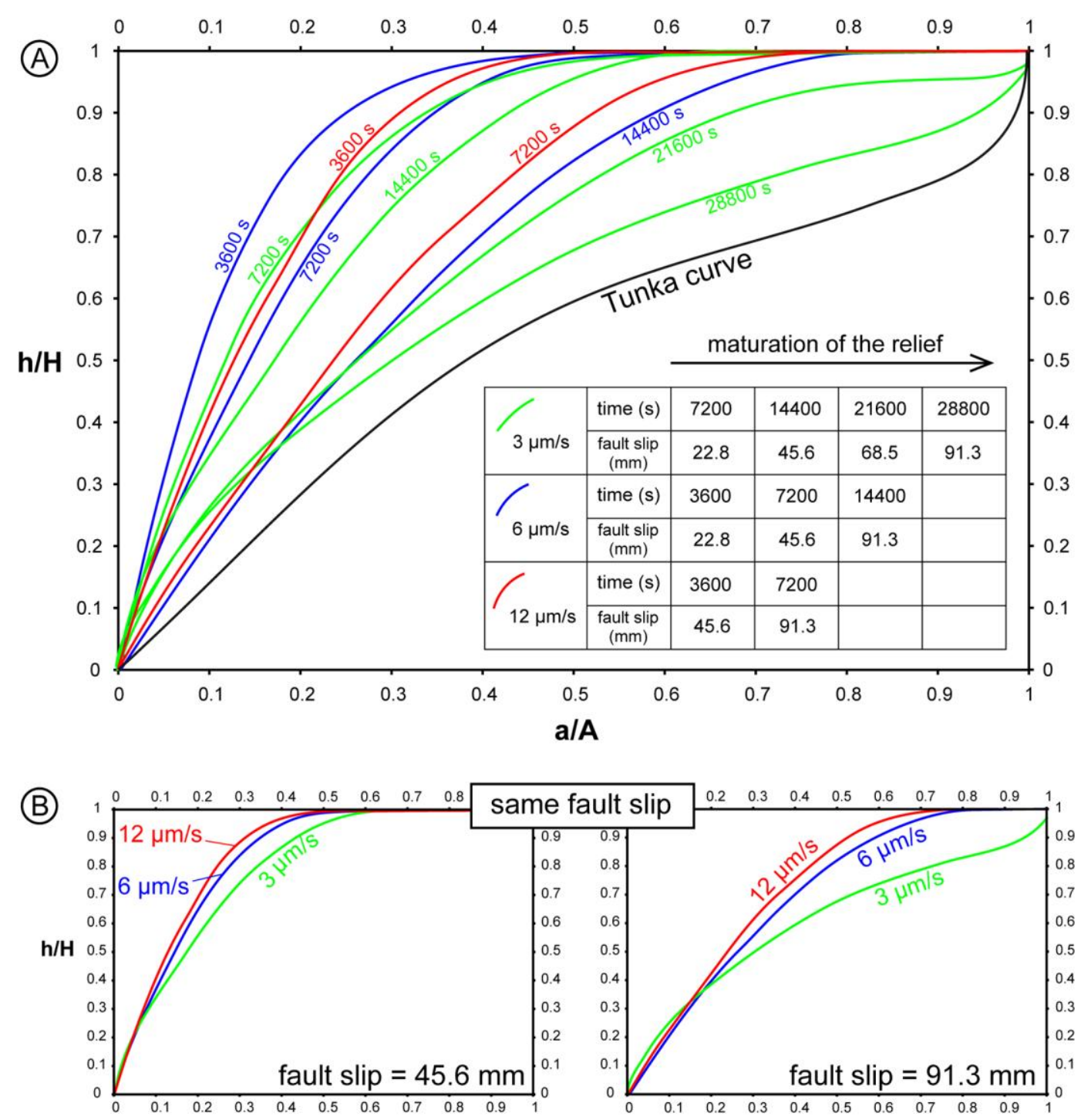

a/A

a/A

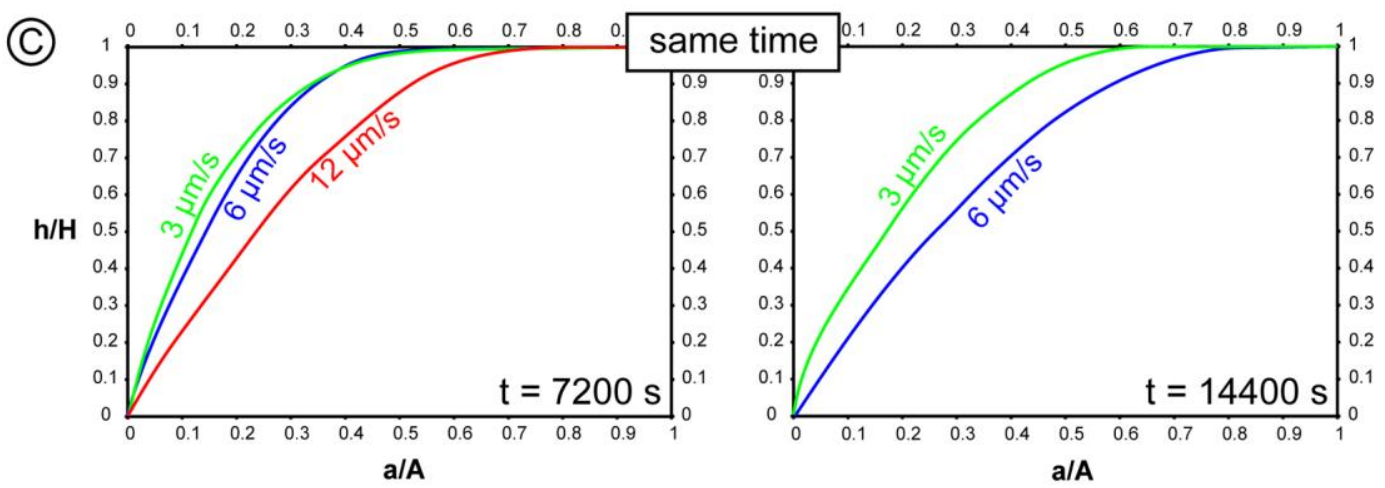


Fig 9

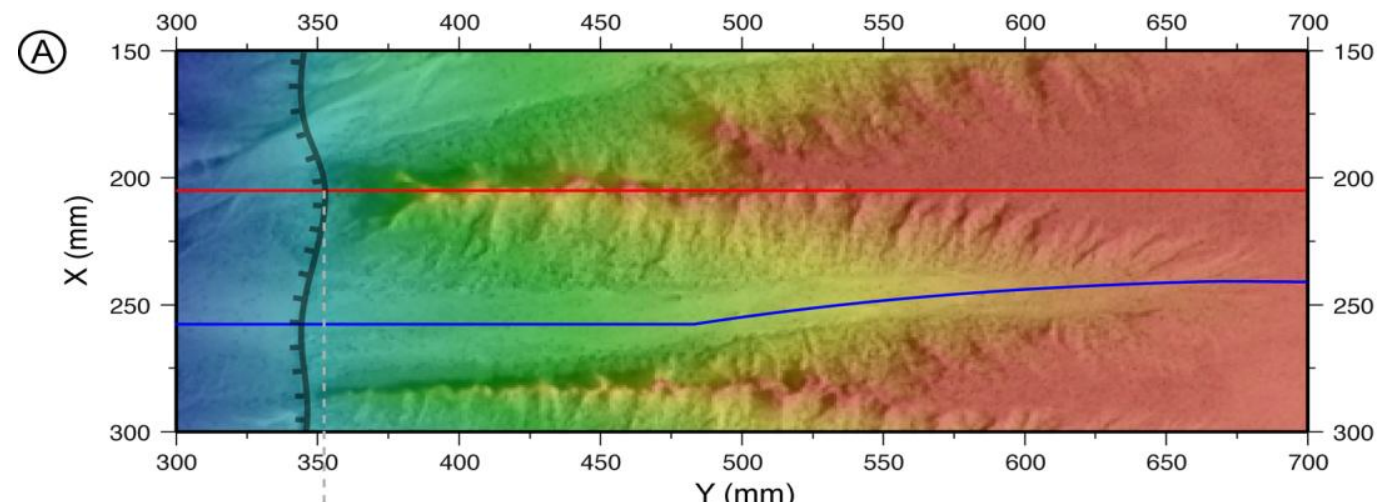

(B)
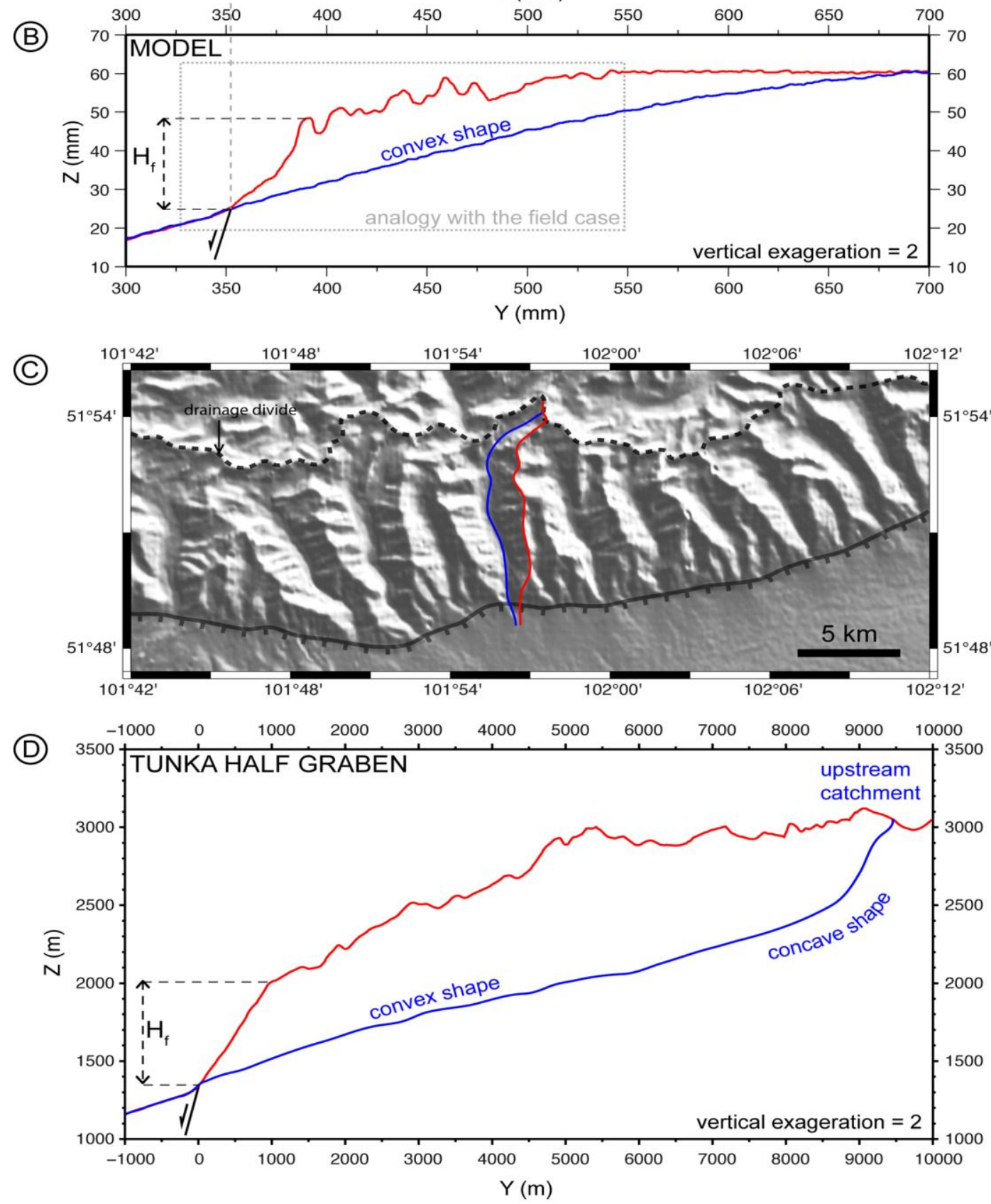
Fig 10
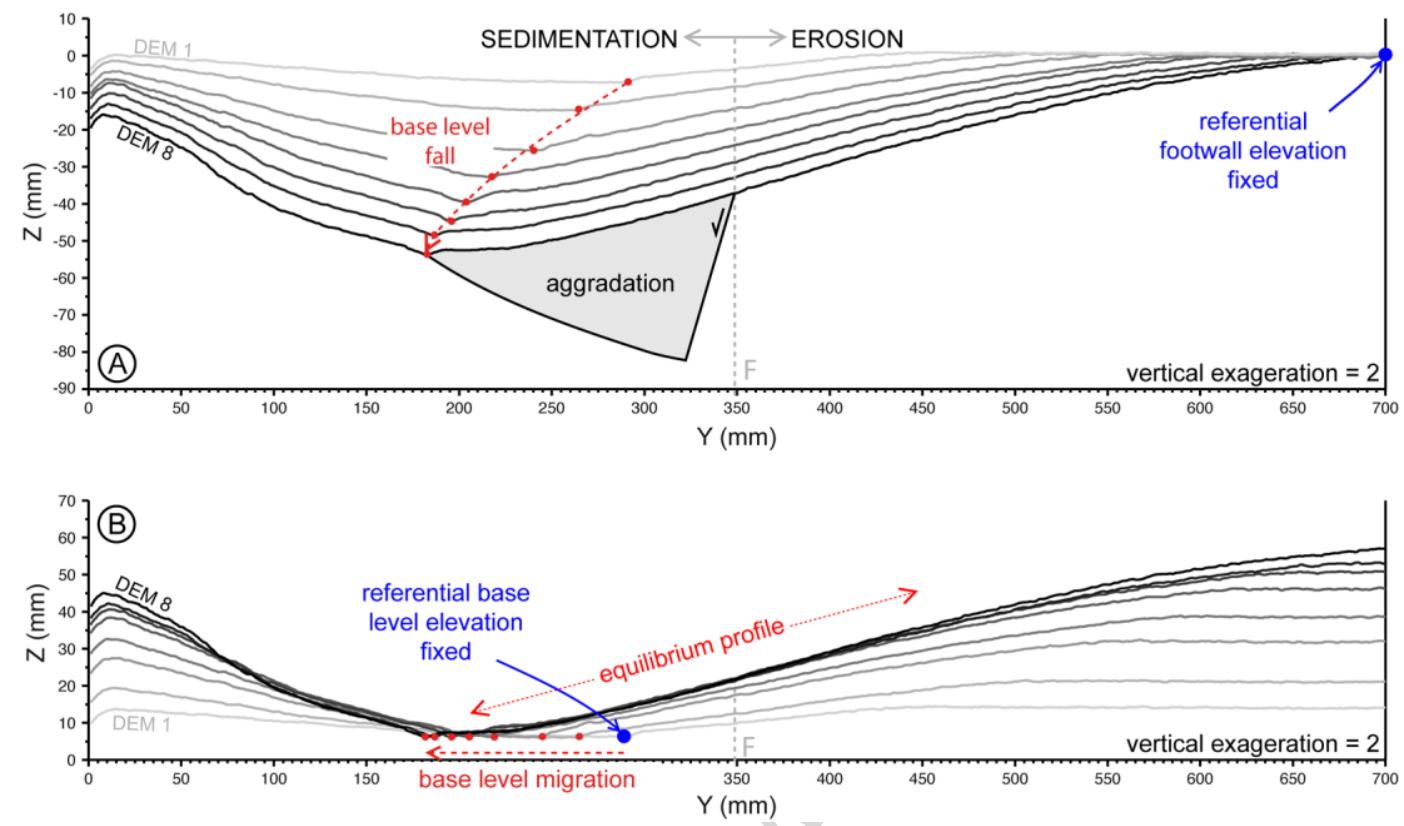
Fig 11

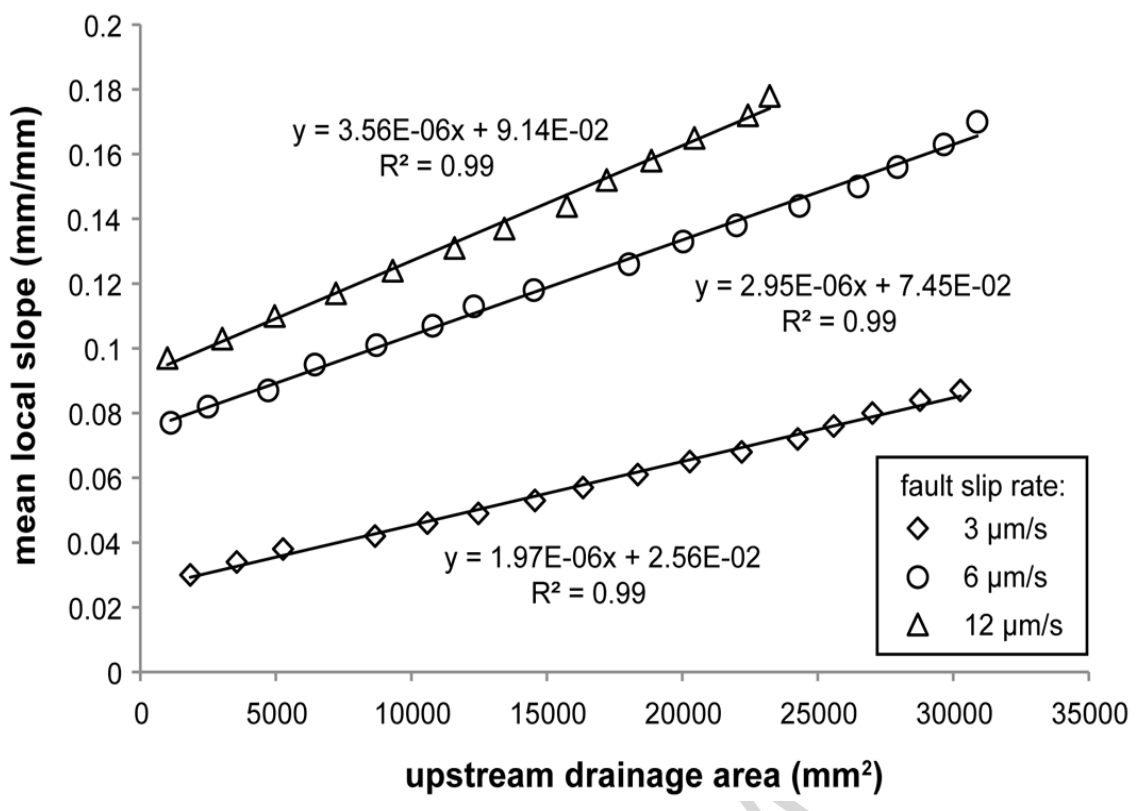


Fig 12
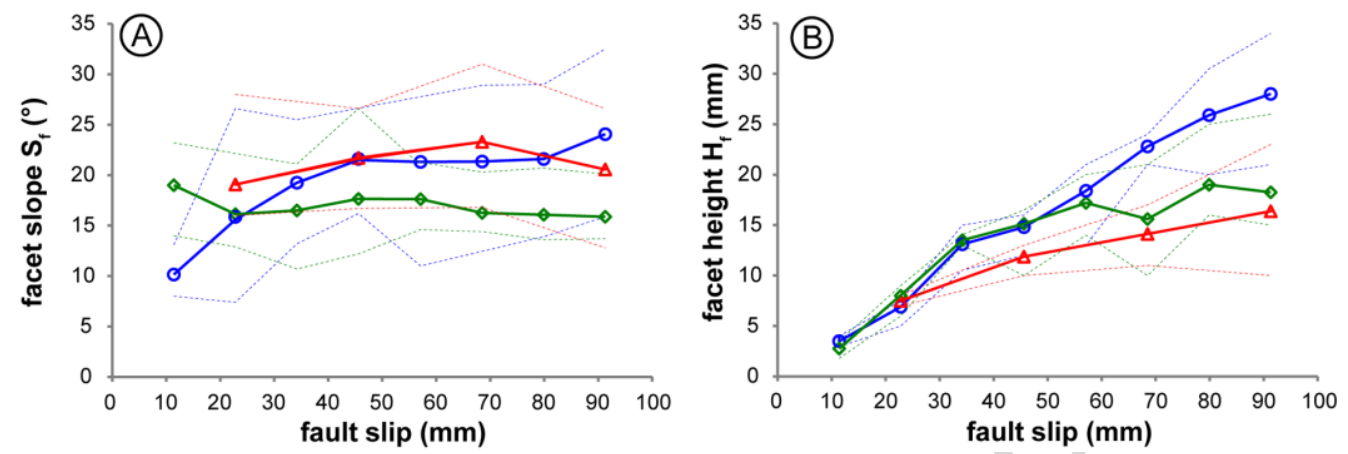

mean fault slip

value: rate:

$\rightarrow 3 \mu \mathrm{m} / \mathrm{s}$

- $6 \mu \mathrm{m} / \mathrm{s}$

$\star \quad 12 \mu \mathrm{m} / \mathrm{s}$

lower or

upper value fault slip (mm) 
Fig 13
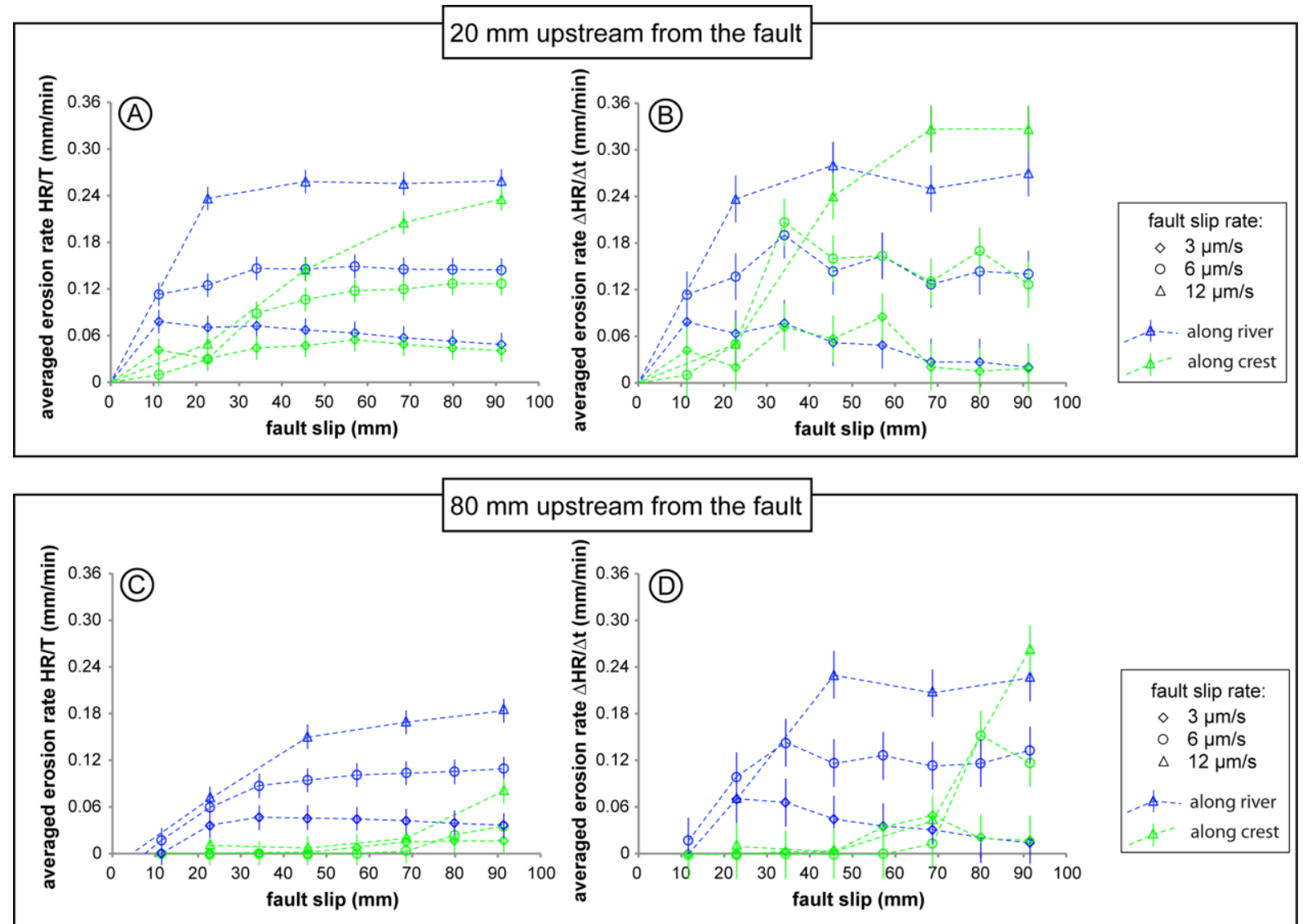
Fig 14

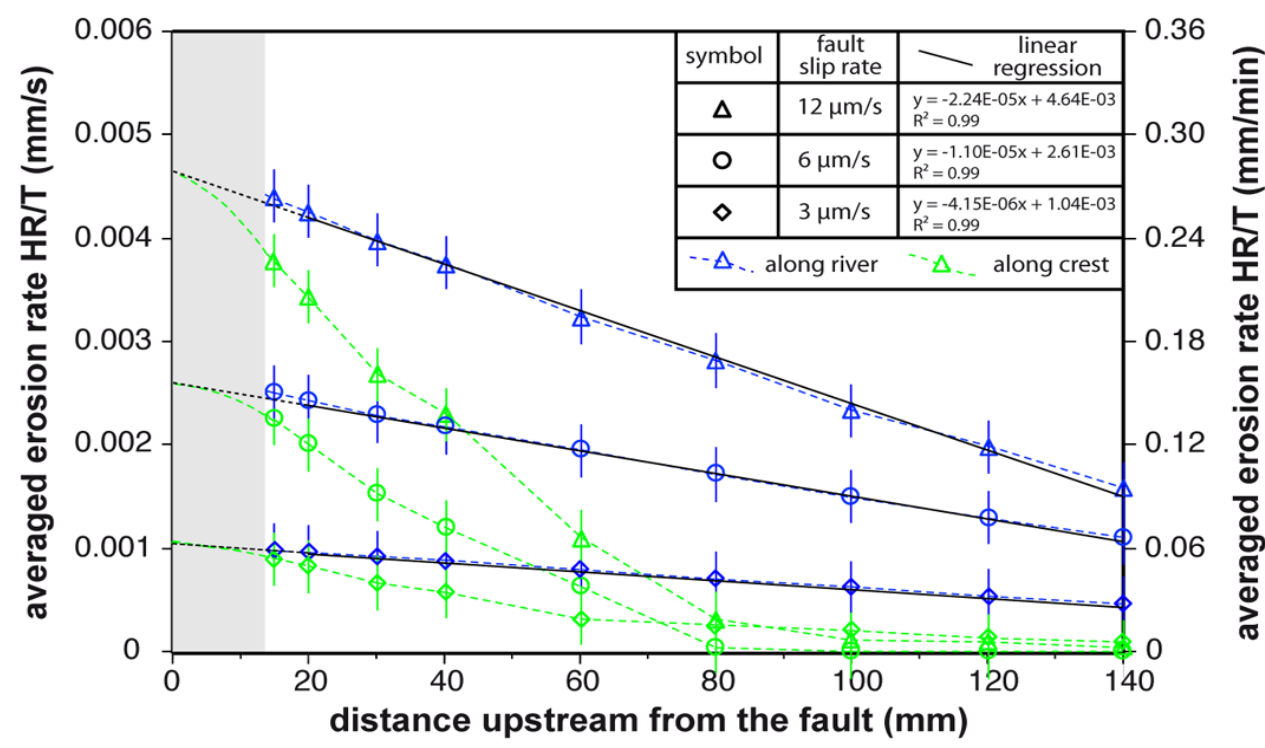


Fig 15
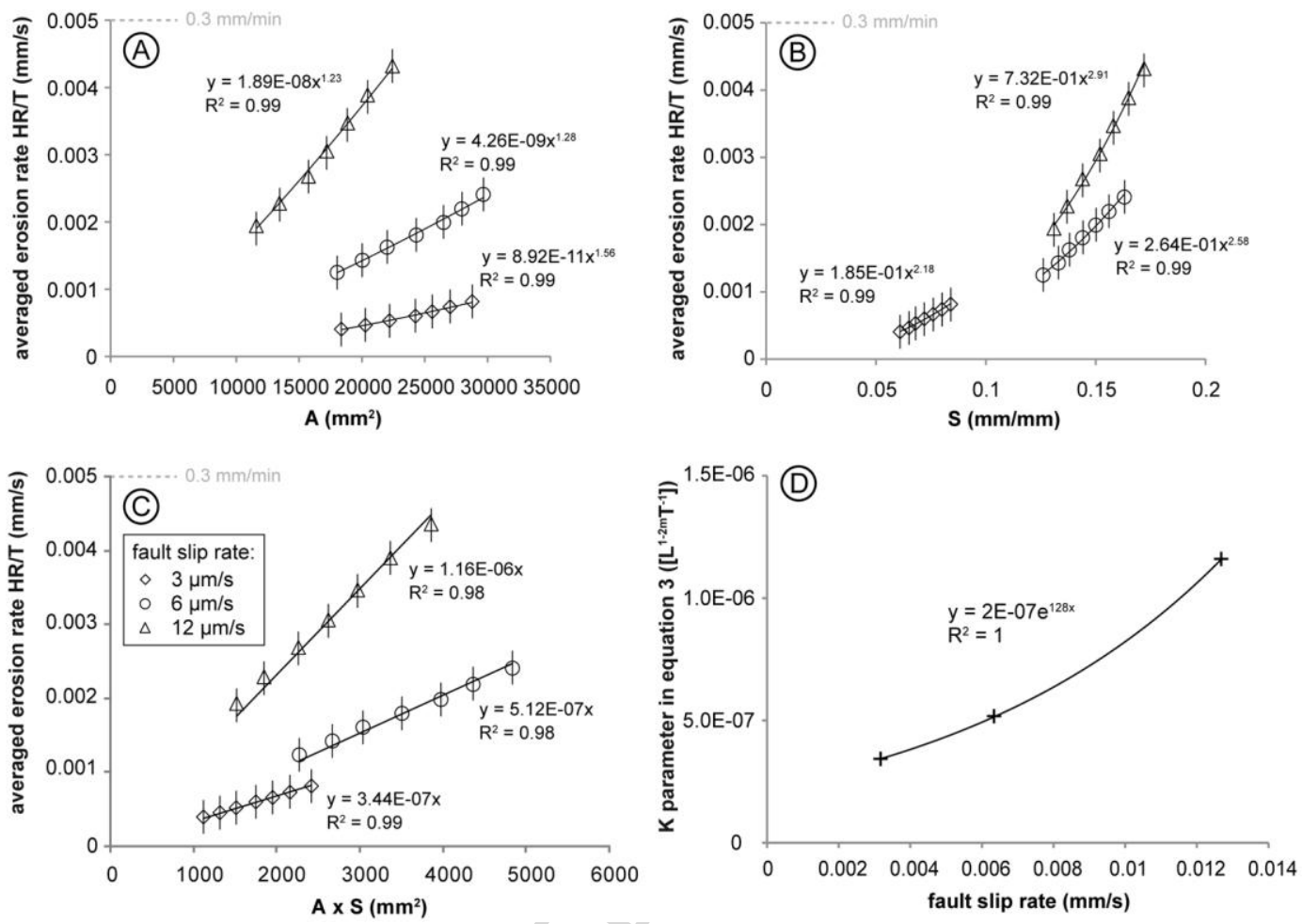
Table 1

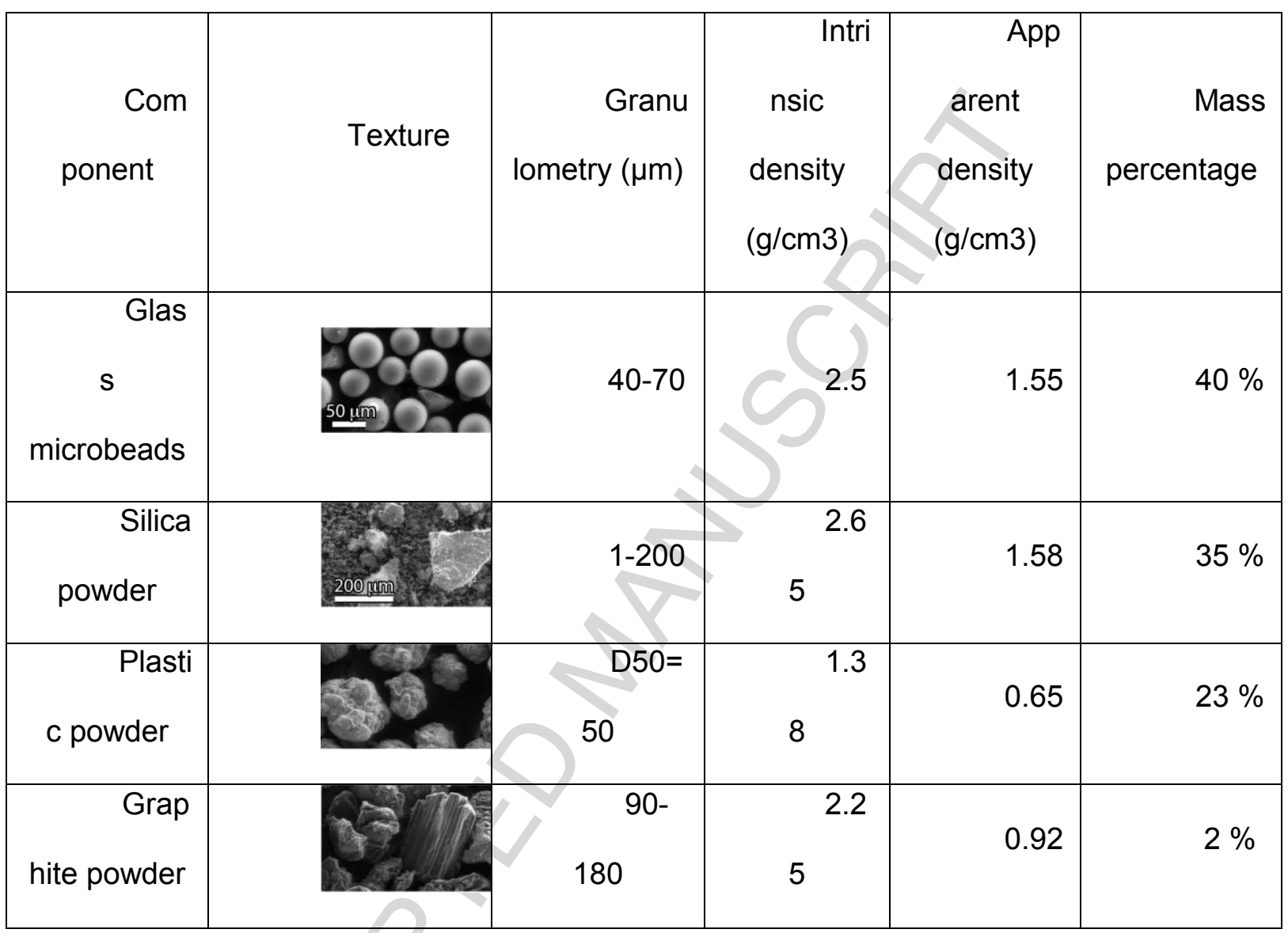


Table 2

\begin{tabular}{|c|c|c|c|c|c|c|c|c|c|c|c|c|c|c|c|c|}
\hline \multirow{3}{*}{$\begin{array}{c}\left.\begin{array}{c}\text { Fault } \\
\text { slip } \\
\text { rate } \\
(\mu \mathrm{m} / \mathrm{s})\end{array}\right) \\
3.17\end{array}$} & \multicolumn{16}{|c|}{ Time and fault slip for successive DEMs } \\
\hline & \multicolumn{2}{|c|}{1} & \multicolumn{2}{|c|}{2} & \multicolumn{2}{|c|}{3} & \multicolumn{2}{|c|}{4} & \multicolumn{2}{|c|}{5} & \multicolumn{2}{|c|}{6} & \multicolumn{2}{|c|}{7} & \multicolumn{2}{|c|}{8} \\
\hline & 3600 & 11.4 & 7200 & 22.8 & 10800 & 34.2 & 14400 & 45.6 & 18000 & 57.1 & 21600 & 68.5 & 25200 & 79.9 & 28800 & 91.3 \\
\hline 6.34 & 1800 & 11.4 & 3600 & 22.8 & 5400 & 34.2 & 7200 & 45.6 & 9000 & 57.1 & 10800 & 68.5 & 12600 & 79.9 & 14400 & 91.3 \\
\hline 12.68 & 1800 & 22.8 & 3600 & 45.6 & 5400 & 68.5 & 7200 & 91.3 & \multirow{3}{*}{\multicolumn{2}{|c|}{$\begin{array}{l}\text { Time since the } \\
\text { initial stage (s) }\end{array}$}} & & & & & & \\
\hline & & & & & & & & & & & & \multicolumn{2}{|c|}{$2 \longleftarrow$} & & 2 & \\
\hline & & & & & & & & & & & & 7200 & 22.8 & & t slip & \\
\hline
\end{tabular}


Highlights

New experimental models allow to study relief evolution along active normal faults.

A quantitative analysis from DEMs of the models is performed.

We succeed in developing the main morphological features of the normal faults.

The fault slip rate controls the erosion rate in rivers and on the hillslopes.

We also evidence the possibility of maintain long-term convex river-long profiles. 